\title{
FRACTIONAL CRYSTALLIZATION LABORATORY TESTS WITH SIMULATED TANK WASTE
}

D. L. Herting

CH2M HILL Hanford Group, Inc.

Richland, WA 99352

U.S. Department of Energy Contract DE-AC27-99RL14047

$\begin{array}{lll}\text { EDT/ECN: } & \text { DRF } & \text { UC: } \\ \text { Cost Center: } & 7 \mathrm{~S} 110 & \text { Charge Code: } \\ \text { B\&R Code: } & & \text { Total Pages: } 34\end{array}$

Key Words: fractional, crystallization, laboratory, tests, simulated, tank, waste, HLW, LAW, treatment, disposal, WTP, dissolved, salts, solids, pretreatment, thermodynamic modeling, simulated, crystallizer, equipment, process, control, SST Early, SST Late, condensate:feed ratios

Abstract: Results are presented for several simulated waste tests related to development of the fractional crystallization process. Product salt dissolution rates were measured to support pilot plant equipment design. Evaporation tests were performed to evaluate the effects of organics on slurry behavior and to determine optimum antifoam addition levels. A loss-of-power test was performed to support pilot plant accident scenario analysis. Envelope limit tests were done to address variations in feed composition.

TRADEMARK DISCLAIMER. Reference herein to any specific commercial product, process, or service by trade name, trademark, manufacturer, or otherwise, does not necessarily constitute or imply its endorsement, recommendation, or favoring by the United States Government or any agency thereof or its contractors or subcontractors.

Printed in the United States of America. To obtain copies of this document, contact: Document Control Services, P.O. Box 950, Mailstop H6-08, Richland WA 99352, Phone (509) 372-2420; Fax (509) 376-4989.

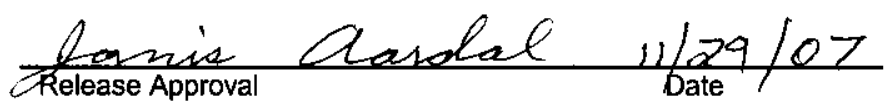

Approved For Public Release

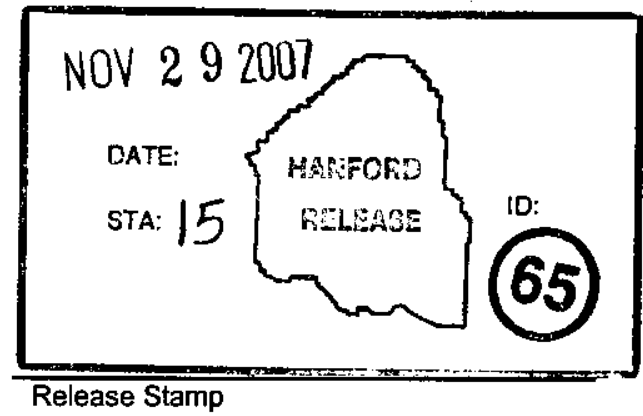




\title{
FRACTIONAL CRYSTALLIZATION LABORATORY TESTS WITH SIMULATED TANK WASTE
}

\author{
D. L. Herting \\ CH2M HILL Hanford Group, Inc.
}

Date Published

November 2007

\section{CH2NMILL \\ Hanford Group, Inc.}

Prepared for the U.S. Department of Energy

Office of River Protection

Contract No. DE-AC27-99RL14047 


\section{TABLE OF CONTENTS}

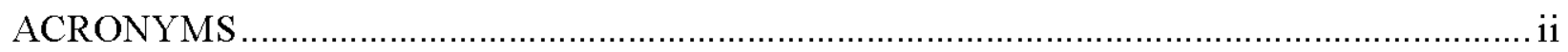

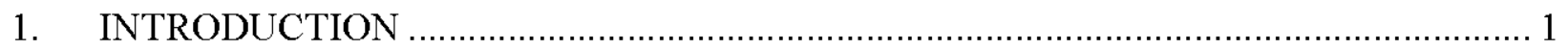

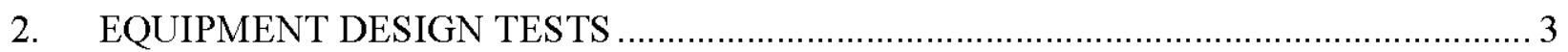

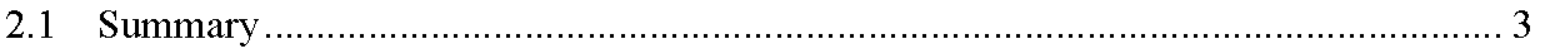

2.2 Process Control Parameters ............................................................................... 5

2.2.1 Temperature Control ............................................................................. 5

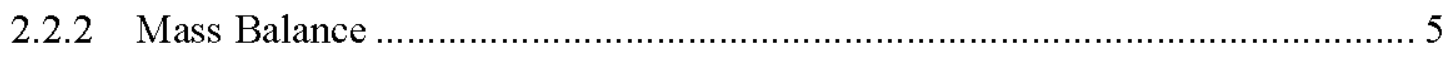

2.2.3 Condensate:Feed Ratio ........................................................................... 5

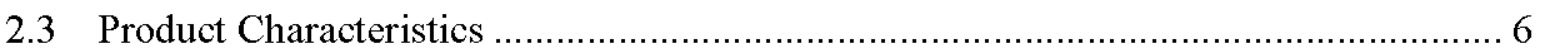

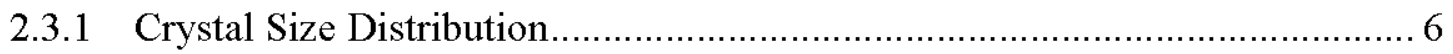

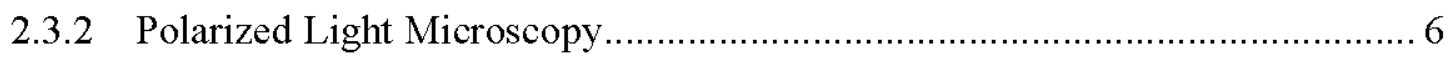

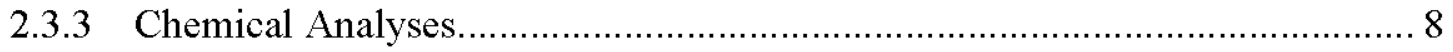

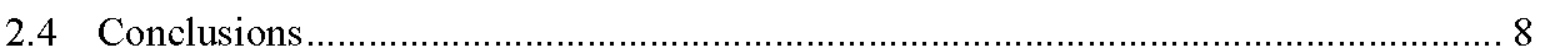

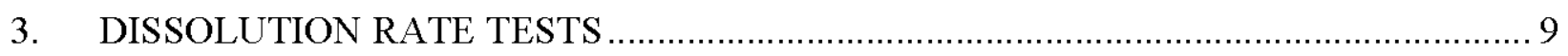

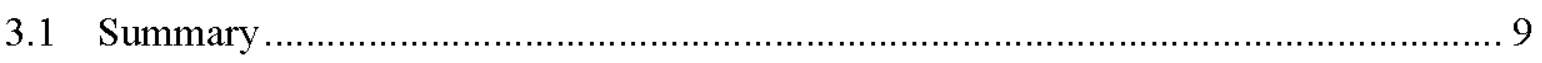

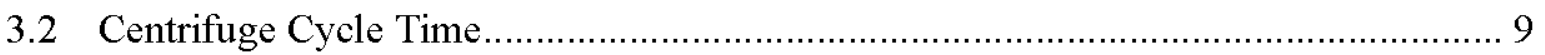

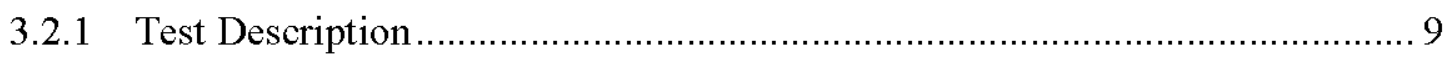

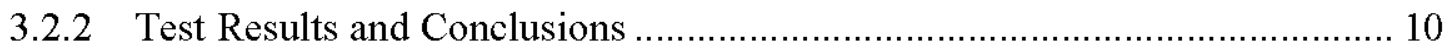

3.3 Feed Reconstitution ................................................................................. 10

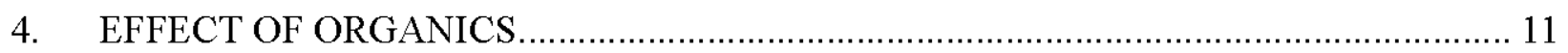

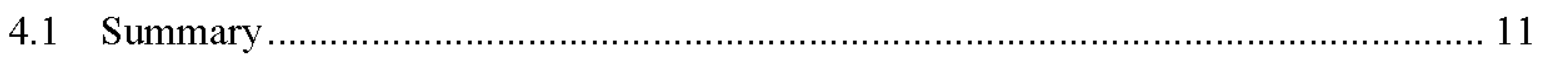

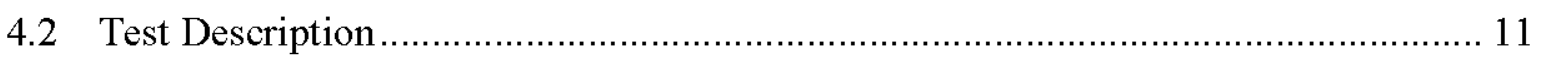

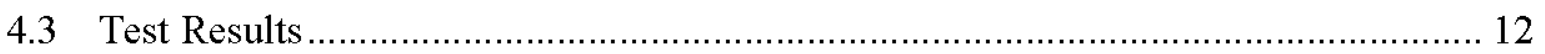

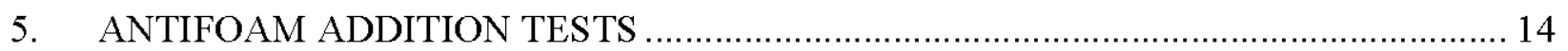

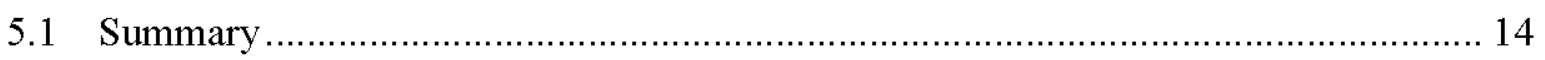

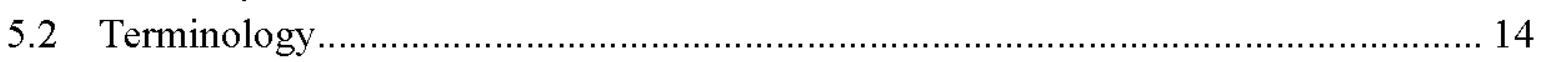

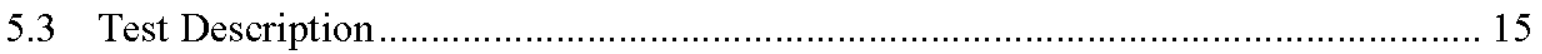

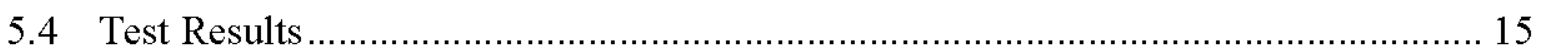

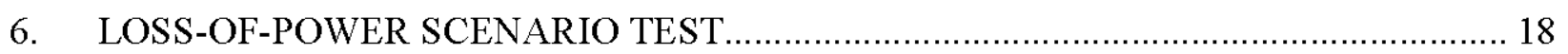

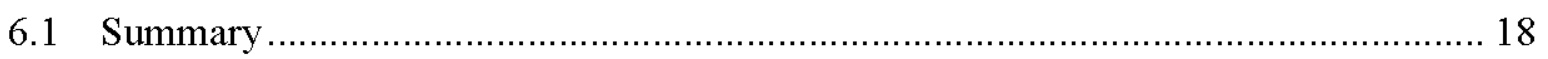

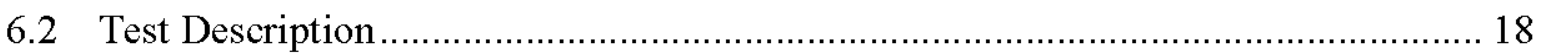

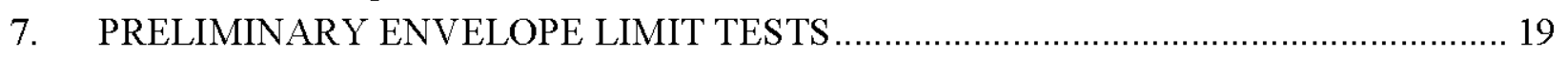

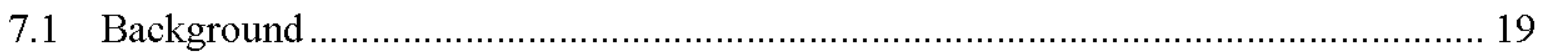

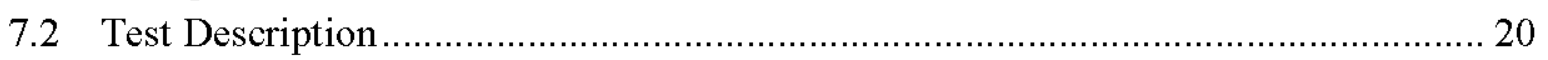

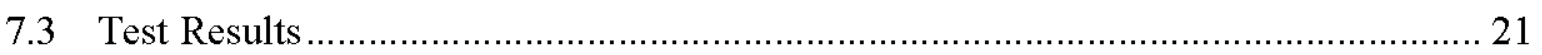

7.3.1 Runs 70/71/72 - Baseline .............................................................. 21

7.3.2 Run 73 - Aluminate at 50\% Saturation (1.6 M Al) ................................... 22

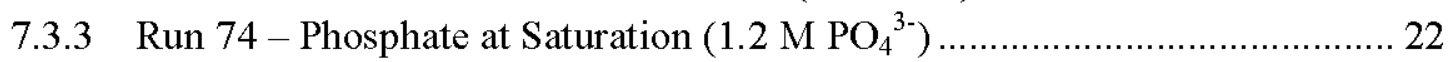

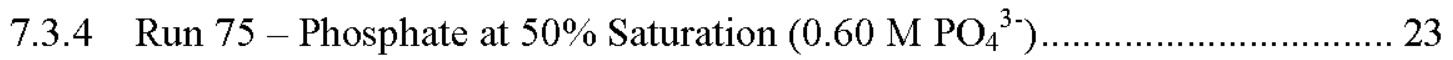




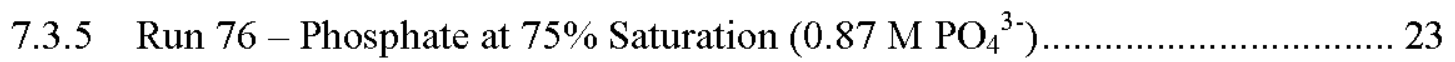

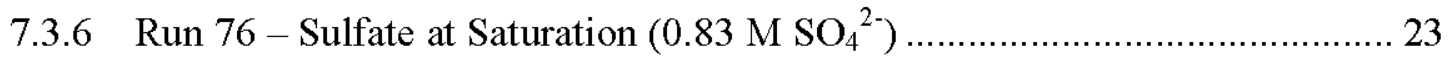

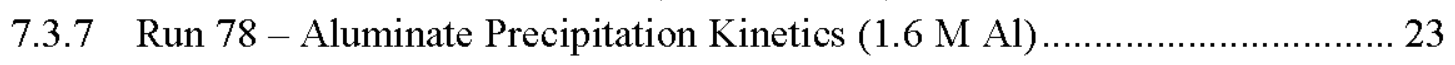

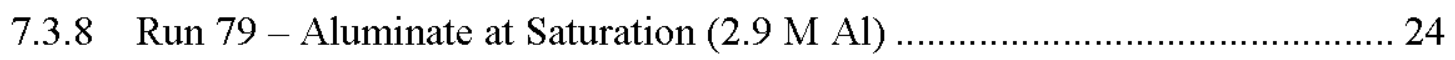

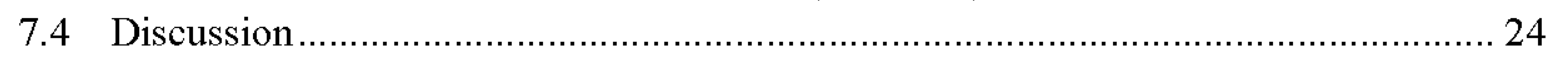

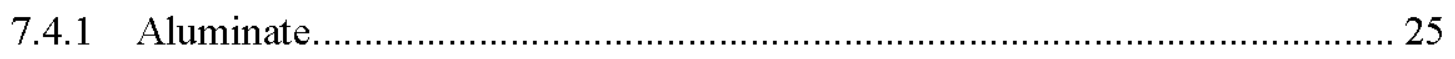

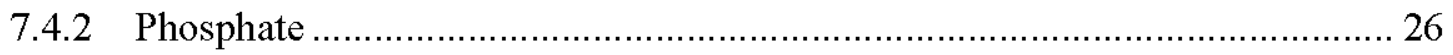

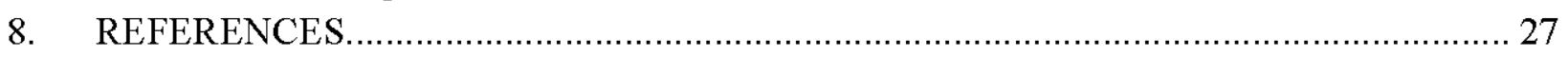

\section{LIST OF FIGURES}

Figure 1-1. 200 West Area Waste Treatment Concept...................................................... 1

Figure 2-1. Schematics of Types of Apparatus................................................................ 4

Figure 2-2. Crystal Size Distribution Curves. [Duplicate analyses shown by two curves (diamonds and squares) on each plot] ...................................................... 7

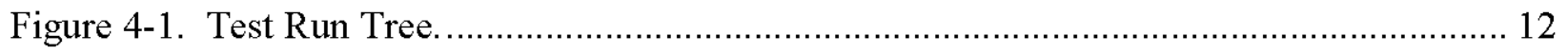

Figure 7-1. Aluminum:Sodium Mole Ratios for $200 \mathrm{~W}$ Area Tanks. ................................ 25

Figure 7-2. Phosphate:Sodium Mole Ratios for $200 \mathrm{~W}$ Area Tanks. ................................... 26

Figure 7-3. Sulfate:Sodium Mole Ratios for $200 \mathrm{~W}$ Area Tanks. ...................................... 27

\section{LIST OF TABLES}

Table 2-1. Major Crystallizer Equipment Design Differences. .............................................. 4

Table 2-2. Overall Mass Balance Data for Stage 1....................................................... 6

Table 4-1. Organic Compounds Added to Prepare 600 Milliliters of SST Early Feed Solution. 11

Table 4-2. Summary of Results from Runs Using Strategy Shown in Figure 4-1................... 13

Table 5-1. Description of Frothing and Bumping Severity Levels..................................... 15

Table 5-2. Summary of Baseline Test Results................................................................... 16

Table 5-3. Summary of Q2-3183A Antifoam Test Results............................................. 17

Table 5-4. Summary of 1520-US Antifoam Test Results................................................ 17

Table 7-1. Feed Envelope Components. ........................................................................ 20

Table 7-2. Summary of Preliminary Envelope Limit Test Results..................................... 22

Table 7-3. Analyte:Sodium Mole Ratios in Feed Solutions. ............................................. 25

\section{ACRONYMS}

$\begin{array}{ll}\text { BBI } & \text { best-basis inventory } \\ \text { C/F } & \text { condensate-to-feed } \\ \text { DF } & \text { decontamination factor } \\ \text { DST } & \text { double-shell tank }\end{array}$


RPP-RPT-35261, Rev. 0

EDTA

Georgia Tech

HEDTA

HLW

IDA

LAW

NTA

PLM

SST

WTP ethylenediaminetetraacetic acid

Georgia Institute of Technology

$\mathrm{N}$-(2-hydroxyethyl)ethylenediaminetriacetic acid

high-level waste

iminodiacetate

low-activity waste

nitrilotriacetic acid

polarized light microscopy

single-shell tank

Waste Treatment and Immobilization Plant 


\section{INTRODUCTION}

The Hanford Site tank farms have 53 million gallons of radioactive waste stored in 149 singleshell tanks (SST) and 28 double-shell tanks (DST). Current waste management plans call for partitioning the waste into two streams for disposal: high-level waste (HLW) for vitrification and disposal in an offsite federal repository, and low-activity waste (LAW) for treatment and disposal on the Hanford Site.

The Waste Treatment and Immobilization Plant (WTP) currently under construction in the $200 \mathrm{E}$ Area is capable of providing the necessary separation processes as well as vitrification of both the HLW and LAW streams. However, the capacity of the WTP is much too limited to treat all of the stored waste before the 2028 deadline established by the Hanford Federal Facility Agreement and Consent Order (Ecology et al. 1989). The capacity of the WTP is capable of completing the vitrification of the HLW but not the LAW during the 40-year design life of these facilities. Therefore, plans have been proposed for supplemental pretreatment to generate the HLW and LAW streams and supplemental treatment for immobilization of the resulting LAW (see Figure 1-1). The fractional crystallization and cesium ion exchange processes have been proposed as supplemental pretreatment methods for saltcake waste retrieved from SSTs. The cesium ion exchange process is being developed as part of the WTP. The focus of the work reported here is the fractional crystallization process.

Figure 1-1. 200 West Area Waste Treatment Concept.

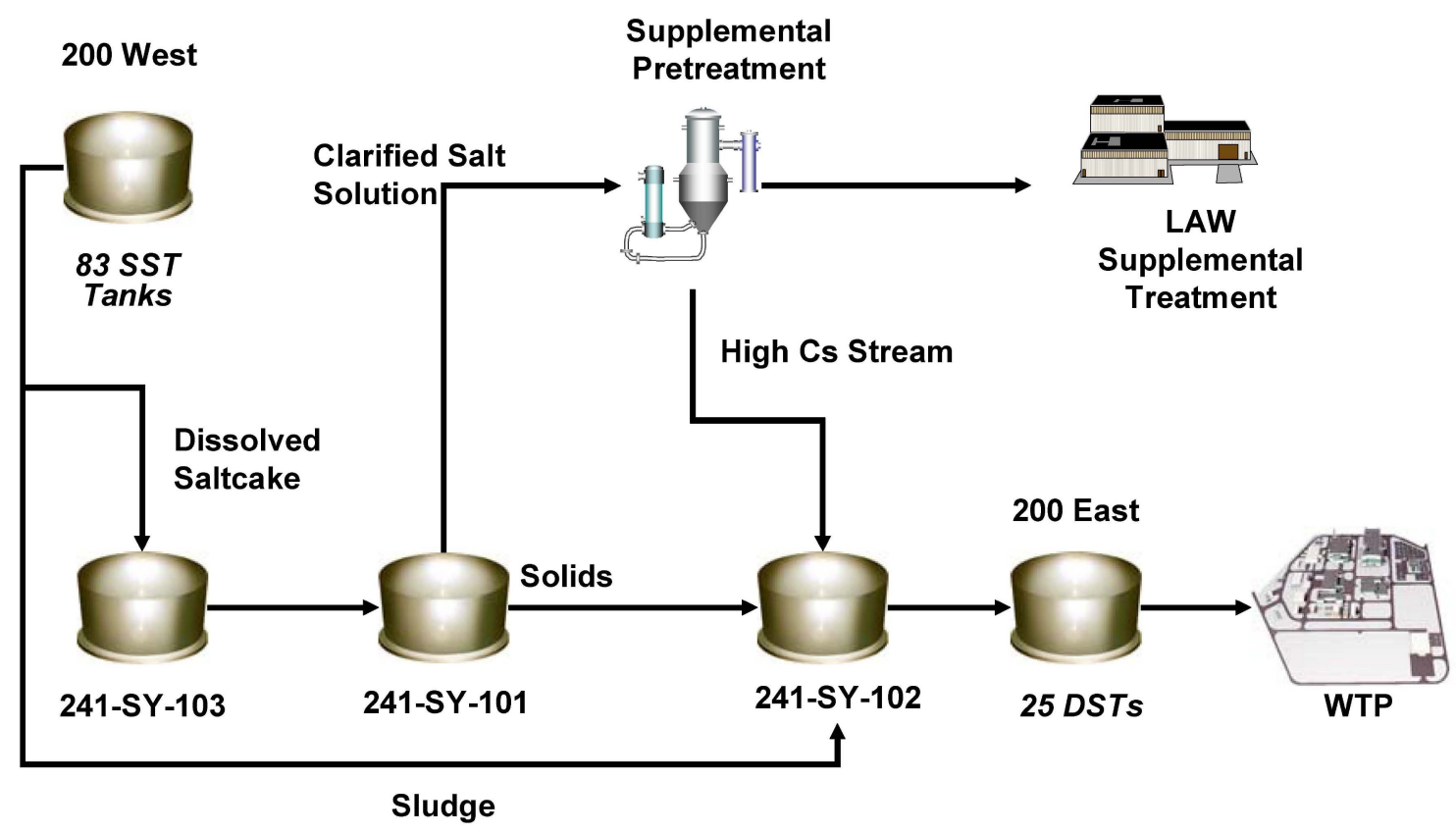

Fractional crystallization is an age-old chemical separation process that takes advantage of differential solubilities of dissolved salts. Dissolved saltcake, the high-sodium liquid waste that results from dissolution and retrieval of the saltcake waste in SSTs, represents the feed for the fractional crystallization process. The feed is first clarified to remove entrained HLW solids, and 
then the clarified feed is evaporated under vacuum until sodium salts precipitate. Concentrations of the major radionuclides present in the liquid waste $-{ }^{137} \mathrm{Cs},{ }^{129} \mathrm{I}$, and ${ }^{99} \mathrm{Tc}$ - are orders of magnitude below their solubility limits, so they remain in the liquid phase as the sodium salts precipitate. Laboratory tests have demonstrated that these radionuclides do not co-precipitate with the sodium salts (RPP-RPT-31998, Fractional Crystallization Laboratory Testing for Inclusion and Co-Precipitation with Actual Tank Waste). Therefore, separation of the solid and liquid phases from the evaporator constitutes separation of the waste into HLW (liquid) and LAW (solid) fractions. The separated solids are readily dissolved in water (process condensate from the evaporator) to generate a liquid LAW stream for feeding to a supplemental treatment process plant.

The viability of the process was first demonstrated on a relatively small laboratory scale with dissolved saltcake from tank 241-S-112 (RPP-RPT-26474, Fractional Crystallization of Waste from Tank 241-S-112). Subsequently, a request for proposals was issued for pretreatment development work, and a contract was awarded to a team led by AREVA NC, Inc. Under this contract, the following development activities are completed or in progress:

a. Thermodynamic modeling: a process flowsheet was developed using thermodynamic modeling software (Environmental Simulation Program by OLI, Inc. ${ }^{1}$ ).

b. Laboratory-scale flowsheet demonstration with simulants: Laboratory-scale equipment for a semi-batch crystallization process was designed and constructed at the Georgia Institute of Technology (Georgia Tech). The equipment was used to optimize process parameters (temperature, evaporation rate, etc.), and to perform proof-of-concept flowsheet tests with several simulated waste feed solutions (RPP-RPT-27239, Hanford Medium/Low Curie Waste Pretreatment Project - Phase I Laboratory Report).

c. Laboratory-scale flowsheet demonstration with actual tank waste: A copy of the equipment used at Georgia Tech was installed in a hot cell at the 222-S Laboratory, and flowsheet demonstration tests were performed using dissolved saltcake from a mixture of waste from nine SSTs from $200 \mathrm{~W}$ Area. Results showed adequate radionuclide decontamination from a single pass (one evaporation step) to provide LAW for a supplemental treatment process. Further results showed that a second pass evaporation could provide sufficient decontamination to provide feed for the LAW melter at the WTP (internal memo 7S110-DLH-07-105, "Product Salt Recrystallization Test Results").

c. Engineering-scale testing: A continuous-flow system using a modified waste simulant was tested by Swenson Technologies, Inc., in Harvey, Illinois. Results were used to define pilot crystallizer system design parameters and to select the type of solid-liquid separation device to be deployed (RPP-RPT-33228, Hanford Medium/Low Curie Waste Pretreatment Alternatives Project - Phase II Report on Pre-Pilot Work at Swenson Technology, Inc. DRAFT). Additional testing was performed at Georgia Tech to observe the effects on crystal properties by varying process parameters (RPP-RPT-32664, Hanford Medium/Low Curie Waste Pretreatment Alternatives Project-Phase II Testing and Demonstration Report, Subtask 2.4).

${ }^{1}$ OLI Systems, Inc., Morris Plains, New Jersey (ESP software). 
d. A one-fifth-scale pilot plant is currently under construction at the Savannah River National Laboratory. It will be operated with simulated waste and is expected to begin operating by January 2008.

Following the successful laboratory-scale process flowsheet demonstrations, a program was put in place to perform laboratory tests to help reduce uncertainties and manage risks associated with pilot plant construction and full-scale plant design. These tests form the basis of this report and include the following:
a. Equipment design for very-small-scale laboratory testing.
b. Dissolution rate tests to support pilot plant flowsheet design.
c. Effect of organics on crystallization and slurry behavior.
d. Antifoam addition tests to determine effectiveness and optimal concentrations.
e. Loss-of-power scenario test to support pilot plant accident scenario analysis.
f. Envelope limit tests to address variations in feed composition.

\section{EQUIPMENT DESIGN TESTS}

\subsection{SUMMARY}

Laboratory-scale flowsheet testing of the fractional crystallization process was conducted on simulated and actual tank waste samples (RPP-PLAN-28979, Hanford Medium/Low Curie Waste Pretreatment Project-Phase II Testing and Demonstration Plan). Simulant tests were performed at Georgia Tech in Atlanta and at the 222-SA laboratory at Hanford. Tests with actual waste were performed in a hot cell at the 222-S Laboratory. Two types of feed samples were tested. The type called "SST Early" represents the composition of dissolved saltcake early in the retrieval process. It contains relatively high concentrations of nitrate, carbonate, hydroxide, and aluminate. The feed type called "SST Late" represents the composition of dissolved saltcake during the later stages of retrieval. It contains relatively high concentrations of the sparingly soluble salts like phosphate, sulfate, fluoride, and oxalate.

Three specific flowsheet tests using simulated SST Early were performed under uniform conditions to test and evaluate the consistency of results between laboratories (Georgia Tech vs. 222-SA laboratory) and between types of apparatus (Georgia Tech crystallizer vs. Hanford boildown apparatus). A full report on the results of the comparison tests is contained in external letter CH2M-0602722, "Fractional Crystallization Simulant Test Comparisons." Highlights of the results are included here.

There are some obvious differences between the Hanford boildown apparatus and the Georgia Tech crystallizer equipment, as shown in Figure 2-1. The major differences are summarized in Table 2-1. The goal of the comparison testing was to determine whether the design differences would result in significant differences in process control parameters or product characteristics. 
Figure 2-1. Schematics of Types of Apparatus.
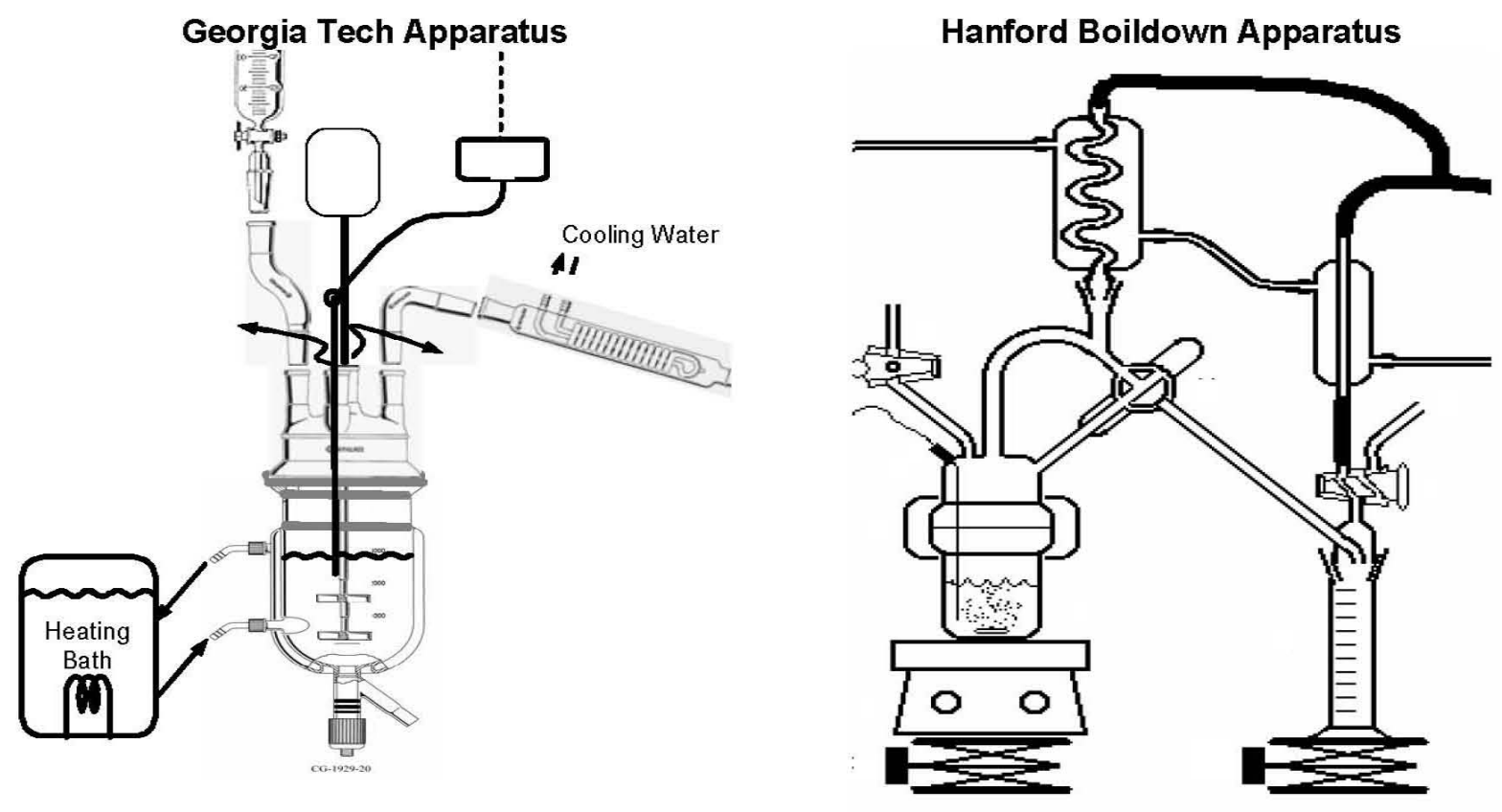

Table 2-1. Major Crystallizer Equipment Design Differences.

\begin{tabular}{|l|l|l|}
\hline \multicolumn{1}{|c|}{ Design Element } & \multicolumn{1}{|c|}{ Georgia Tech } & \multicolumn{1}{c|}{ Hanford } \\
\hline Shape of crystallizer & Round-bottom flask & Flat-bottom cylindrical pot \\
\hline Stirring method & $\begin{array}{l}\text { Overhead mechanical stirrer with blades } \\
\text { in contact with liquid phase only }\end{array}$ & $\begin{array}{l}\text { Magnetically coupled stirbar in } \\
\text { contact with liquid and glass bottom }\end{array}$ \\
\hline Heating method & $\begin{array}{l}\text { Hot liquid (initially silicon oil, switched } \\
\text { later to water due to concerns about in- } \\
\text { cell use) circulating through jacket } \\
\text { surrounding crystallizer }\end{array}$ & $\begin{array}{l}\text { Ceramic hot plate in contact with } \\
\text { bottom of boildown pot }\end{array}$ \\
\hline Condensate collection & $\begin{array}{l}\text { By weight, with condensate flask } \\
\text { resting on balance }\end{array}$ & $\begin{array}{l}\text { By volume, with condensate collected } \\
\text { in graduated cylinder }\end{array}$ \\
\hline Data collection & Continual collection by computer link & Intermittent manual data entry \\
\hline
\end{tabular}

The three comparison tests are the following:

a. Run $38 \mathrm{~b}-$ Georgia Tech crystallizer; run performed at Georgia Tech.

b. Run 41 - Georgia Tech crystallizer; run performed at 222-SA laboratory.

c. Run 42 - Hanford boildown apparatus; run performed at 222-SA laboratory.

The results of the three tests indicate there is good agreement between laboratories and between types of apparatus used to perform the tests. These results lend assurance to the validity of comparing simulant test results at Georgia Tech with the actual tank waste tests performed at 
222-S Laboratory. The results also provide confidence that additional process support testing may be carried out using the simpler-to-operate and smaller-volume Hanford apparatus.

\subsection{PROCESS CONTROL PARAMETERS}

Each of the three comparison tests involved a two-stage process. In Stage 1, the feed solution was evaporated at a constant $66^{\circ} \mathrm{C}$ until a predetermined condensate:feed $(\mathrm{C} / \mathrm{F})$ ratio was reached. The target $\mathrm{C} / \mathrm{F}$ ratio was taken from the computer-modeled flowsheet for the SST Early feed and was designed to produce a slurry containing $30 \mathrm{wt} \%$ solids. The slurry was filtered to produce a filter cake and clear filtrate. The solids were washed with a high-sodium brine before being collected as the Stage 1 product salt. The filtrate was evaporated further in Stage 2 at a constant $40{ }^{\circ} \mathrm{C}$ until again reaching $30 \mathrm{wt} \%$ solids in the slurry. The slurry was filtered and washed to collect the Stage 2 product salt, and the filtrate became the purge liquid (the HLW stream).

The full report (CH2M-0602722) includes detailed results for both stages of operation. For purposes of clarity and brevity, the discussion here is limited to Stage 1. Results for the second stage were analogous.

\subsubsection{Temperature Control}

In both types of apparatus, the temperature is held constant at preset levels $\left(66^{\circ} \mathrm{C}\right.$ for Stage 1$)$ by manually adjusting the system pressure. The ionic strength of the solution continually increases during evaporation, so the resulting boiling point elevation drives the need to continually reduce the pressure to maintain a constant boiling temperature.

In all three tests the boiling temperature was maintained to within $\pm 1.4{ }^{\circ} \mathrm{C}$ of the target temperature. Adequate temperature control is possible with either system.

\subsubsection{Mass Balance}

Weights were recorded for all of the conveniently measured input and output process streams, allowing the determination of an overall process mass balance. Data for the overall mass balance are shown in Table 2-2. In general, the data demonstrate that both laboratories and both sets of apparatus within the same laboratory gave similar performance in terms of mass balance accountability.

\subsubsection{Condensate:Feed Ratio}

The evaporation endpoint for each test was determined by the $\mathrm{C} / \mathrm{F}$ ratio. For Stage 1 , the target $\mathrm{C} / \mathrm{F}$ ratio was 0.474 for all three runs and was taken directly from the feed and condensate flowsheet values. Actual $\mathrm{C} / \mathrm{F}$ ratios achieved were $0.481,0.467$, and 0.474 for Runs $38 \mathrm{~b}$, 41, and 42 , respectively. 
RPP-RPT-35261, Rev. 0

Table 2-2. Overall Mass Balance Data for Stage 1.

\begin{tabular}{|c|c|c|c|c|}
\hline & Stream & Run 38b & Run 41 & Run 42 \\
\hline \multirow[t]{3}{*}{ In } & Feed & $1,565.45$ & $1,370.73$ & $1,324.17$ \\
\hline & Wash liquid & 334.28 & 385.89 & 352.39 \\
\hline & Total in & $1,899.73$ & $1,756.62$ & $1,676.56$ \\
\hline \multirow[t]{7}{*}{ Out } & Condensate & 753.03 & 639.95 & 627.12 \\
\hline & Washed solids & 209.71 & 199.41 & 211.21 \\
\hline & Filtrate & 385.86 & 404.62 & 364.15 \\
\hline & Spent wash & 377.31 & 388.36 & 372.14 \\
\hline & Accumulation $^{a}$ & 136.90 & 37.45 & 12.89 \\
\hline & Known losses ${ }^{b}$ & 28.47 & 50.05 & 64.47 \\
\hline & Total out & $1,891.28$ & $1,719.84$ & $1,651.98$ \\
\hline \multicolumn{2}{|c|}{ Overall mass balance ( $\%$ recovered) } & $99.6 \%$ & $97.9 \%$ & $98.5 \%$ \\
\hline
\end{tabular}

${ }^{a}$ Accumulation is defined as nondrainable solids formed inside the apparatus, mainly on glass surfaces above the slurry level.

${ }^{\mathrm{b}}$ Known losses are quantifiable losses including analytical samples and beaker/filter residues.

The actual evaporation endpoint differed more than the $\mathrm{C} / \mathrm{F}$ ratios would indicate because of the buildup of "accumulation," the solid residue that remains in the crystallizer (or boildown apparatus) after the slurry is drained. The weight of accumulation (see Table 2-2) was significantly lower in the two runs in the 222-SA laboratory than in the run at Georgia Tech, suggesting that the degree of difference is due to decisions regarding when to terminate the evaporation rather than the type of crystallizer.

\subsection{PRODUCT CHARACTERISTICS}

\subsubsection{Crystal Size Distribution}

Crystal size distribution curves are shown in Figure 2-2. Each curve is determined by a sieve analysis in which the product crystals are washed with acetone, air dried, gently crushed to disrupt weak aggregates, and pre-sieved through the largest-diameter sieve in the stack.

Results indicate that somewhat larger crystals were produced by the Hanford boildown apparatus in Stage 1. (In Stage 2, not shown, the crystals produced by the boildown apparatus were intermediate in size between the two Georgia Tech crystallizer runs.) The amount of "fines" (crystals below $100 \mu \mathrm{m}$ in size) was very low in all cases.

\subsubsection{Polarized Light Microscopy}

Polarized light microscopy (PLM) was used at both laboratories to identify the solid phases produced in the tests and examine the crystal morphologies. Polarized light microscopy is a qualitative rather than quantitative tool. Qualitatively, there was good agreement between the laboratories and between the two sets of apparatus at the 222-SA laboratory in terms of the types and morphologies of crystals produced. The major phases identified by PLM in their approximate order of abundance for all three tests are as follows:

$$
\mathrm{NaNO}_{3}>\mathrm{Na}_{2} \mathrm{CO}_{3} \cdot \mathrm{H}_{2} \mathrm{O}>\mathrm{Na}_{6} \mathrm{CO}_{3}\left(\mathrm{SO}_{4}\right)_{2}>\mathrm{Na}_{2} \mathrm{C}_{2} \mathrm{O}_{4} .
$$


RPP-RPT-35261, Rev. 0

Figure 2-2. Crystal Size Distribution Curves.

[Duplicate analyses shown by two curves (diamonds and squares) on each plot]

Run 38b,

Georgia Tech Apparatus at Georgia Tech

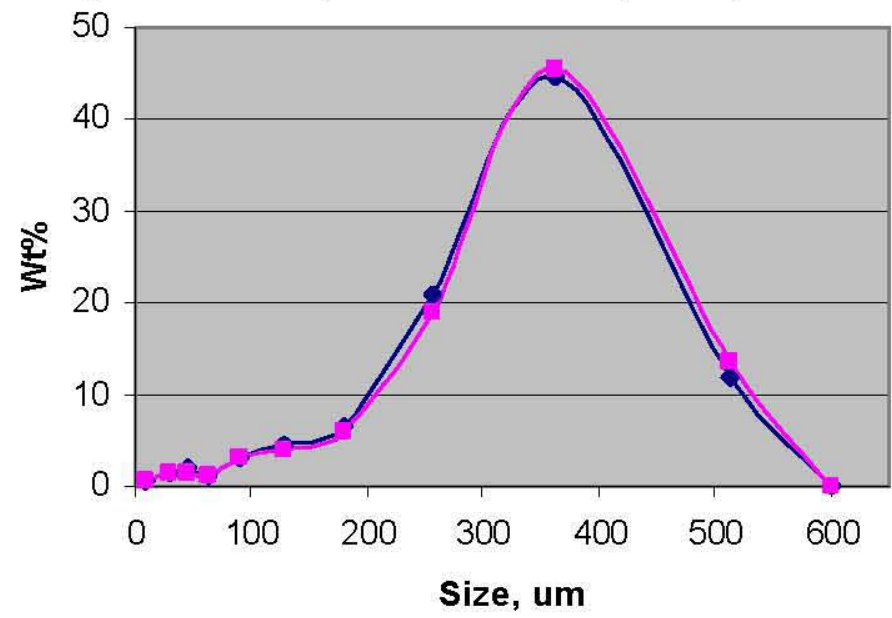

Run 41, Georgia Tech Apparatus at 222-SA

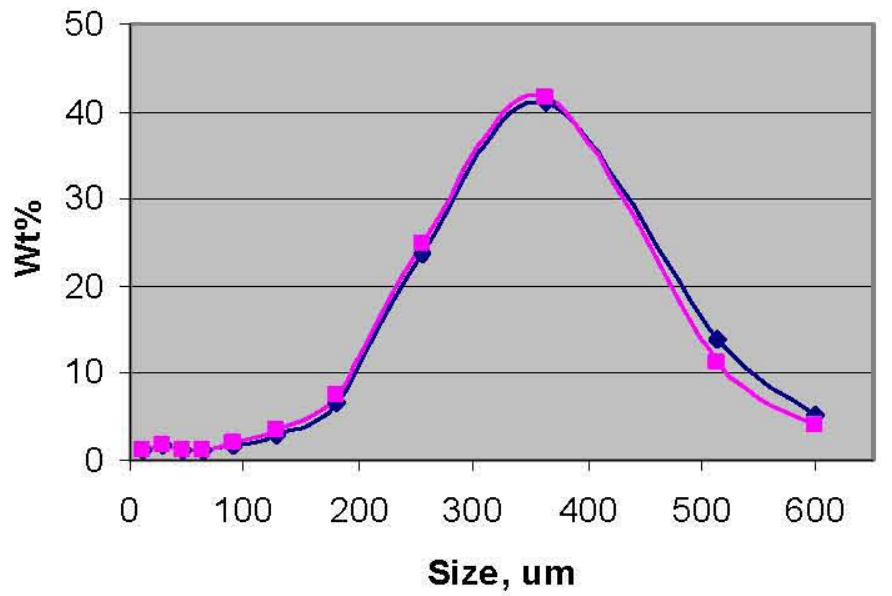

Run 42, Hanford Boildown Apparatus at 222-SA

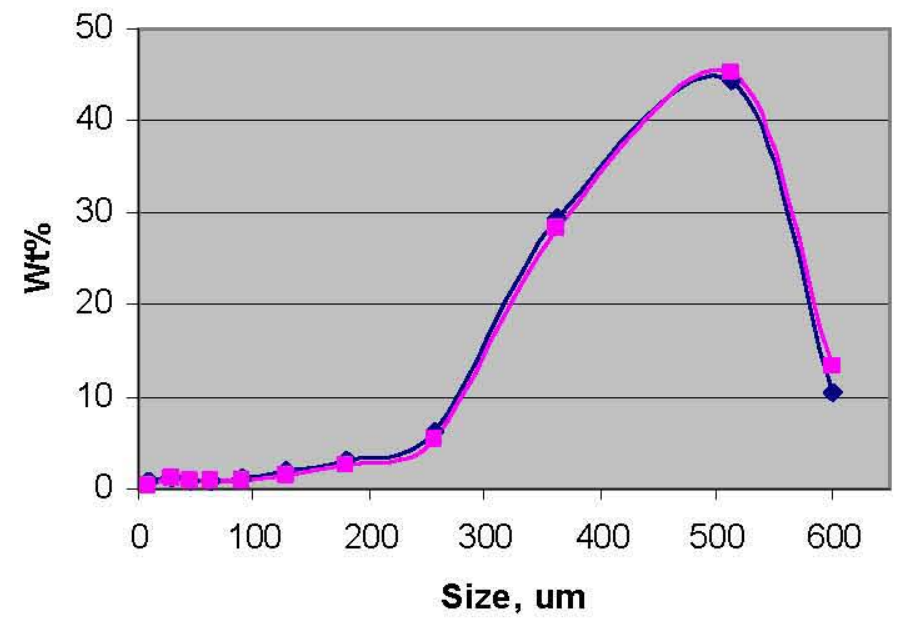




\subsubsection{Chemical Analyses}

Several sample points in each flowsheet test were analyzed for the principal elements present in the feed: $\mathrm{Al}, \mathrm{Cs}, \mathrm{Cr}, \mathrm{P}, \mathrm{Na}$, and $\mathrm{S}$. In general, the results showed very good agreement between the two laboratories and between the two sets of apparatus.

Concentrations of species that are not expected to crystallize ( $\mathrm{Al}, \mathrm{Cs}$, and $\mathrm{Cr}$ ) were found to be higher in the filtrate than in the feed, as expected. The opposite was true for $\mathrm{S}$, as expected, due to precipitation of burkeite, $\mathrm{Na}_{6} \mathrm{CO}_{3}\left(\mathrm{SO}_{4}\right)_{2}$.

Similar arguments hold for the expected trends in the series of samples taken after each of the five wash steps. Elements not present in the solid phase crystals ( $\mathrm{Al}, \mathrm{Cs}, \mathrm{Cr}$, and $\mathrm{P}$ ) showed steady decreases in concentration with each wash, while elements that were present mainly in the solid phase (Na and $\mathrm{S}$ in Stage 1) showed relatively little change from one wash to the next.

The composition of the accumulation was also interesting. The concentration of soluble species $(\mathrm{Al}, \mathrm{Cs}$, and $\mathrm{Cr}$ ) was a little lower in the accumulation than in the filtrate; $\mathrm{Na}$ was roughly two times more concentrated in the accumulation; S was 12-23 times higher in the accumulation. The concentrations of all soluble species were very much higher in the accumulation than in the washed solids in all cases, while the concentrations of crystallized species were close to the same in the accumulation and washed solids. All of these findings follow the anticipated trends for an accumulation composed of undifferentiated dried slurry.

\subsection{CONCLUSIONS}

The chemical and physical nature of the process appears to be sufficiently robust that test results lead to similar conclusions regardless of the laboratory or equipment used to perform the test. In other words, a certain set of operational parameters (temperature, evaporation rate, $\mathrm{C} / \mathrm{F}$ ratio) should be expected to provide a given set of results (amount and chemical composition of solid phase, crystal size distribution, crystal morphology) whether the test is performed at Georgia Tech, performed at the 222-SA laboratory using the Georgia Tech apparatus, or performed at the 222-SA laboratory using the Hanford boildown apparatus.

For purposes of maintaining the best possible comparisons between simulated and actual waste testing, the Georgia Tech apparatus was loaded into a hot cell at 222-S Laboratory for use in performing the flowsheet tests with actual tank waste (RPP-RPT-31352, Fractional Crystallization Flowsheet Tests with Actual Tank Waste). However, given that the boildown apparatus has some advantages for this type of testing (e.g., smaller-size samples, easier operation, and shorter overall test duration), the Hanford boildown apparatus was selected for most of the follow-up process development testing described in Chapters 3 through 7. 
RPP-RPT-35261, Rev. 0

\section{DISSOLUTION RATE TESTS}

\subsection{SUMMARY}

Two types of dissolution rate tests were performed in support of the flowsheet and equipment design for the pilot plant being constructed at the Savannah River Site.

The first set of tests was designed to determine how fast the product centrifuged solids would dissolve in the $8 \mathrm{M} \mathrm{Na}^{+}$solution in the product dissolver tank. The dissolution rate is tied to the centrifuge cycle time. The washed filter cake from one centrifuge batch is dissolved in process condensate in the product dissolver tank, and a portion of the resulting solution is used to wash the cake in the subsequent centrifuge cycle.

The second test was designed to test whether the process feed solution could be reconstituted quickly enough to support continuous operation of the plant. The pilot plant produces three main product streams: washed filter cake (sodium salt crystals), process condensate (water), and concentrated centrate (the purge liquid). On a once-through basis, the volume of available feed solution $(10,000 \mathrm{gal})$ is sufficient for the evaporator to reach steady-state conditions, operate for several hours at steady state, and then shut down. If the three product streams can be recombined quickly enough, the reconstituted feed could be used to keep the evaporator operating at steady state indefinitely (i.e., for several days, weeks, or months instead of several hours).

A full report of the dissolution rate tests is found in internal memos 7S110-DLH-07-101, "Report on Dissolution Rate Tests," and 7S110-DLH-07-119, "Final Report on Dissolution Rate Tests." Highlights from the reports are presented here.

\subsection{CENTRIFUGE CYCLE TIME}

In the pilot plant, the crystallizer product slurry will be fed from the slurry collection tank to the centrifuge, which will operate in batch mode. The slurry is fed continuously until the filter cake is approximately $45-\mathrm{mm}$ thick on the centrifuge bowl, at which time the valve to the slurry collection tank is closed. The filter cake is then washed with $8 \mathrm{M} \mathrm{Na}^{+}$solution from the product dissolution tank. The washed cake is discharged ("dumped") from the centrifuge to the product dissolution tank, and the process starts over. The centrifuge cycle time (feed/wash/dump) will take approximately 4 min.

\subsubsection{Test Description}

In one set of tests, a 1-L glass beaker representing the product dissolver tank was charged with $700 \mathrm{~mL}$ of $8 \mathrm{M} \mathrm{Na}^{+}$solution, representing a 100-gal heel of liquid in the dissolver tank. The solution was mixed with a magnetic stirbar and adjusted to the test temperature (either 40 or $60^{\circ} \mathrm{C}$ ). A 43-g aliquot of water was added $(6.1$ gal of process condensate at $1.52 \mathrm{gal} / \mathrm{min})$, and $38.5 \mathrm{~g}$ of product salt was added, representing $51.3 \mathrm{lb}$ of filter cake discharge $(2.7 \mathrm{gal} @$ $19 \mathrm{lb} / \mathrm{gal})$. The progress of the dissolution was monitored by visual observation and videotaping. (The process volumes and densities quoted here are taken from the pilot plant flowsheet.) 
In the next set of tests, dissolution time for the two major product salts $\left(\mathrm{NaNO}_{3}\right.$ and $\mathrm{Na}_{2} \mathrm{CO}_{3} \cdot \mathrm{H}_{2} \mathrm{O}$ ) in $10 \mathrm{M} \mathrm{Na}^{+}$solution was measured. This time, a 1-L glass beaker was charged with $800 \mathrm{~mL}$ of the $10 \mathrm{M}$ solution. The appropriate amount of water was added, and the solution was adjusted to $55^{\circ} \mathrm{C}$. A mixture of $\mathrm{NaNO}_{3}$ and $\mathrm{Na}_{2} \mathrm{CO}_{3}$ reagent salts was added (8.0:1.2 mole ratio), and a timer was started. At 1 -min intervals beginning at $\mathrm{t}=0$, a $50-\mathrm{mL}$ aliquot of the slurry was filtered. The filter membranes were air dried and weighed to determine the weight of undissolved solids remaining in the slurry.

\subsubsection{Test Results and Conclusions}

At both temperatures, nearly all of the salt dissolved in $3 \mathrm{~min}$, but a trace of solids persisted for much longer. The trace of solids became more persistent with each successive test. The solid phase responsible for the persistent cloudiness was identified as sodium fluoride sulfate, $\mathrm{Na}_{3} \mathrm{FSO}_{4}$. As a result of these findings, a filter was added to the pilot plant to clarify the wash solution for the centrifuge.

The second set of tests was performed to test whether dissolution of just the major product salts was sufficiently fast to support the centrifuge cycle time if the filter were incorporated into the system. Results showed that the major salts were $90 \%$ dissolved in $1 \mathrm{~min}$ and reached saturation $(99.7 \%$ dissolved) in $3 \mathrm{~min}$. The dissolution is fast enough to support the pilot plant centrifuge cycle time.

\subsection{FEED RECONSTITUTION}

A baseline (flowsheet conditions) simulated-waste SST Early flowsheet test was performed using the Hanford boildown apparatus. At the conclusion of the run, the three major productsfiltrate, washed saltcake (with accumulation added), and condensate-were recombined to reconstitute the original feed. Based on flowsheet predictions, approximately one half of the condensate would be used to dilute the purge stream (filtrate) and the other half would be used to dissolve the centrifuge cake (filter cake). A summary of the run follows:

a. Input: $250 \mathrm{~mL}$ SST Early feed, density $1.311 \mathrm{~g} / \mathrm{mL}$ at $22{ }^{\circ} \mathrm{C}$, evaporated at $60^{\circ} \mathrm{C}$ to $150 \mathrm{~mL}$ condensate; $155 \mathrm{~g}$ slurry delivered to filter.

b. Product stream 1: $84 \mathrm{~g}$ filtrate diluted with $75 \mathrm{~g} \mathrm{H}_{2} \mathrm{O}$ (half of the condensate); solution remained clear after $18 \mathrm{hr}$ at ambient temperature $\left(22^{\circ} \mathrm{C}\right)$; density $1.249 \mathrm{~g} / \mathrm{mL}$ at $22{ }^{\circ} \mathrm{C}$.

c. Product stream 2: $61 \mathrm{~g}$ washed filter cake $+18 \mathrm{~g}$ accumulation dissolved in $75 \mathrm{~g} \mathrm{H}_{2} \mathrm{O}$ (the other half of the condensate); dissolution nearly complete in $10 \mathrm{~min}$; some solids remaining after $30 \mathrm{~min}$ identified as $\mathrm{Na}_{2} \mathrm{C}_{2} \mathrm{O}$ 4, averaging $10 \mu \mathrm{m} \times 1.5 \mu \mathrm{m}$; bulk density of almost-clear solution $1.375 \mathrm{~g} / \mathrm{mL}$ at $21^{\circ} \mathrm{C}$.

d. Reconstituted feed: combined streams 1 and 2; solution clarified in $<10$ min (i.e., the sodium oxalate solids dissolved); density of combined solution $1.308 \mathrm{~g} / \mathrm{mL}$ at $22{ }^{\circ} \mathrm{C}-$ nearly the same as the original feed.

Conclusion: Feed reconstitution can be accomplished quickly enough to support continuous pilot plant operation. 


\section{EFFECT OF ORGANICS}

These tests were performed at Georgia Tech and reported in RPP-RPT-34136, Hanford Medium/Low Curie Waste Pretreatment Alternatives Project-Phase II Subtask 2.5 and Subtask 2.6. Results are summarized here to provide context and background for subsequent work performed at Hanford (Chapter 5).

\subsection{SUMMARY}

Batch evaporative crystallization runs were conducted with simulated SST Early Feed solutions containing organic species. The results demonstrated that the organics created substantial processing difficulties. The problems included (1) foaming that was so severe there was significant carryover of slurry from the crystallizer into the condenser and condensate receiver, (2) coating of the walls of the crystallizer with an amorphous solid, and (3) substantial difficulties in filtering the product crystals.

A sequential series of runs was conducted to identify those organic species most likely to be the cause(s) of the observed problems. There was extensive foaming in the crystallizer in any of the runs in which ethylenediaminetetraacetic acid (EDTA) and/or $\mathrm{N}$-(2-hydroxyethyl)ethylenediaminetriacetic acid (HEDTA) were present, and it was determined that EDTA was responsible for film formation on the walls of the crystallizer. The four species that led to solid-liquid separation difficulties were EDTA, HEDTA, nitrilotriacetic acid (NTA), and sodium citrate. The organics EDTA, HEDTA, and NTA changed the texture of the filter cake and reduced draining efficiency of mother liquor.

\subsection{TEST DESCRIPTION}

The organic species added to the SST Early feed simulant are shown in Table 4-1.

Table 4-1. Organic Compounds Added to Prepare 600 Milliliters of SST Early Feed Solution.

\begin{tabular}{|l|l|c|c|}
\hline Compound & \multicolumn{1}{|c|}{ Formula } & Mass (g) & Molarity \\
\hline Sodium formate & $\mathrm{NaCOOH}$ & 6.89 & 0.169 \\
\hline Sodium acetate & $\mathrm{Na}\left(\mathrm{C}_{2} \mathrm{H}_{3} \mathrm{O}_{2}\right)$ & 2.13 & 0.043 \\
\hline Sodium glycolate & $\mathrm{Na}\left(\mathrm{C}_{2} \mathrm{H}_{3} \mathrm{O}_{3}\right)$ & 4.27 & 0.073 \\
\hline Trisodium citrate dihydrate & $\mathrm{Na}_{3}\left[\mathrm{C}_{6} \mathrm{H}_{5} \mathrm{O}_{7}\right] \cdot 2 \mathrm{H}_{2} \mathrm{O}$ & 4.33 & 0.025 \\
\hline Tetrasodium EDTA ( $\left.\mathrm{Na}_{4} \mathrm{EDTA}\right)$ & $\mathrm{Na}_{4}\left[\mathrm{C}_{10} \mathrm{H}_{12} \mathrm{~N}_{2} \mathrm{O}_{8}\right]$ & 4.16 & 0.016 \\
\hline Trisodium HEDTA (Na $\left.{ }_{3} \mathrm{HEDTA}\right)$ & $\mathrm{Na}_{3}\left[\mathrm{C}_{10} \mathrm{H}_{15} \mathrm{~N}_{2} \mathrm{O}_{7}\right]$ & 4.28 & 0.019 \\
\hline Disodium 2,2'-Iminodiacetate (IDA) & $\mathrm{Na}_{2}\left[\mathrm{C}_{4} \mathrm{H}_{5} \mathrm{NO}_{4}\right]$ & 2.22 & 0.014 \\
\hline Trisodium nitrilotriacetate monohydrate (NTA) & $\mathrm{Na}_{3}\left[\mathrm{C}_{6} \mathrm{H}_{6} \mathrm{NO}_{6}\right] \cdot \mathrm{H}_{2} \mathrm{O}$ & 0.52 & 0.003 \\
\hline
\end{tabular}

A branched methodology shown schematically in Figure 4-1 was followed to identify organic species responsible for process difficulties. An initial run (Run 56) was performed without any of the organic species and compared to a similar run with all of the species (Run 57). The organic species were divided into two branches according to their chemical functionality (carboxylates and amines), and runs were performed sequentially to eliminate those that did not cause process difficulties. For example, the species present in Run 60 did not lead to any process 
difficulties, which means that $\mathrm{C} 1$ and $\mathrm{C} 2$ were harmless and the individual runs with these species were unnecessary.

Figure 4-1. Test Run Tree.

$\mathrm{C} 1$ = sodium formate; $\mathrm{C} 2$ = sodium acetate; $\mathrm{C} 3$ = sodium glycolate; $\mathrm{C} 4$ = sodium citrate; A1 $=\mathrm{Na}_{4}$ EDTA; A2 = Na ${ }_{3} \mathrm{HEDTA} ; \mathrm{A} 3=\mathrm{Na}_{2} \mathrm{IDA} ; \mathrm{A} 4=\mathrm{Na}_{3} \mathrm{NTA}$.

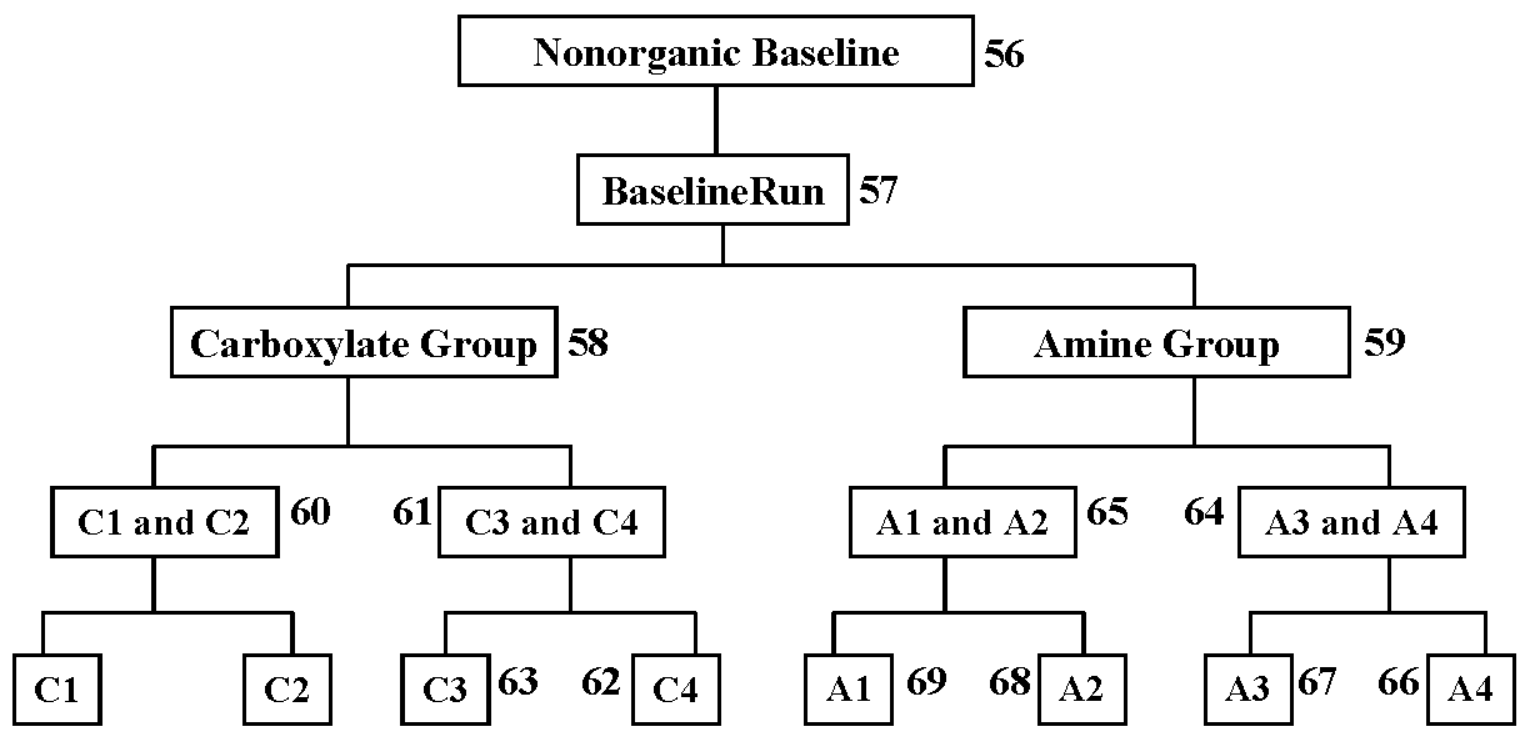

\subsection{TEST RESULTS}

Each run was judged based on the following criteria: (1) ease of solid-liquid separation, (2) formation of an organic film on the jacketed walls of the crystallizer, (3) alteration of the crystal population, and (4) evidence of foaming during the evaporation stage. A summary of these results is shown in Table 4-2.

As shown in Table 4-2, there was extensive foaming in the crystallizer in any of the runs in which EDTA and/or HEDTA were present, although it was somewhat less vigorous when only EDTA was present. Foaming was so intense during Runs 59, 65, and 68 that mother liquor was entrained up through the vessel neck and contaminated the condensate stream. This did not occur during Run 69. The data also lead to the conclusion that EDTA was responsible for film formation on the walls of the crystallizer. The HEDTA may have added to the film thickness, but EDTA was the primary cause of the film formation.

Table 4-2 also provides qualitative information (S-L separation) on the handling characteristics of the slurries generated in the runs with organic additives. These results identified sodium formate, sodium acetate, sodium glycolate, and iminodiacetate (IDA) as having essentially no impact on the processing characteristics. Note that the slurries from runs containing only these species (Runs 60, 63, and 67) had essentially the same filtration and washing properties as that from Run 56; moreover, the appearance and gross composition of the constituent crystals were the same as those from the nonorganic baseline Run 56. 
RPP-RPT-35261, Rev. 0

Table 4-2. Summary of Results from Runs Using Strategy Shown in Figure 4-1.

\begin{tabular}{|c|l|c|c|c|l|}
\hline Run & Organic Species & $\begin{array}{c}\text { S-L } \\
\text { Separation }\end{array}$ & $\begin{array}{c}\text { Vessel } \\
\text { Film } \\
\text { Formation }\end{array}$ & $\begin{array}{c}\text { Vessel Froth } \\
\text { Formation }\end{array}$ & \multicolumn{1}{|c|}{ Crystal Population } \\
\hline 56 & None & $30 \mathrm{~min}$ & No & No & Typical \\
\hline 57 & All & $45 \mathrm{~min}$ & Yes & Yes (slight) & $\begin{array}{l}\text { No carbonate or burkeite } \\
\text { crystals, larger nitrate crystals }\end{array}$ \\
\hline 58 & All carboxylates & No & No & $\begin{array}{l}\text { No burkeite crystals but } \\
\text { formed sodium sulfate crystals }\end{array}$ \\
\hline 59 & All amines & $60 \mathrm{~min}$ & Yes & Yes (intense) & $\begin{array}{l}\text { No carbonate or burkeite } \\
\text { crystals, very small nitrate } \\
\text { crystals }\end{array}$ \\
\hline 60 & Formate and acetate & $30 \mathrm{~min}$ & No & No & Typical \\
\hline 61 & Glycolate and citrate & $45 \mathrm{~min}$ & No & No & $\begin{array}{l}\text { No burkeite crystals but } \\
\text { formed sodium sulfate crystals }\end{array}$ \\
\hline 62 & Citrate & $45 \mathrm{~min}$ & No & No & $\begin{array}{l}\text { Typical, but smaller nitrate } \\
\text { crystals }\end{array}$ \\
\hline 63 & Glycolate & $30 \mathrm{~min}$ & No & No & Typical \\
\hline 64 & IDA and NTA & $45 \mathrm{~min}$ & No & No & $\begin{array}{l}\text { Very small amounts of } \\
\text { carbonate and burkeite }\end{array}$ \\
\hline 65 & EDTA and HEDTA & $20 \mathrm{~min}$ & Yes & Yes (extreme) & $\begin{array}{l}\text { Very small amounts of } \\
\text { carbonate and burkeite }\end{array}$ \\
\hline 66 & NTA & $50 \mathrm{~min}$ & No & No & $\begin{array}{l}\text { Trace amounts of carbonate } \\
\text { and burkeite }\end{array}$ \\
\hline 67 & IDA & $25 \mathrm{~min}$ & No & No & Typical \\
\hline 68 & HEDTA & $20 \mathrm{~min}$ & No & Yes (extreme) & $\begin{array}{l}\text { Trace of burkeite crystals but } \\
\text { also formed sodium sulfate }\end{array}$ \\
\hline 69 & EDTA & $40 \mathrm{~min}$ & Yes & $\begin{array}{c}\text { Yes (less intense } \\
\text { than Run } 68)\end{array}$ & $\begin{array}{l}\text { Trace of large burkeite and } \\
\text { small amount of elongated } \\
\text { carbonate crystals, larger } \\
\text { nitrate }\end{array}$ \\
\hline
\end{tabular}

The four species that led to solid-liquid separation difficulties were EDTA, HEDTA, NTA, and sodium citrate. The organics EDTA, HEDTA, and NTA changed the texture of the filter cake and reduced draining efficiency of mother liquor. This led to increased filtration and washing times and also gave the final product a yellowish color. Sodium citrate did not appear to alter the texture of the filter cake or the color of the final product, but it did cause longer filtration times. During the run with citrate there was some filter plugging, which led to reduced separation efficiency and difficulty stirring the filter cake.

Additional experimental details and a thorough discussion of the measured crystal size distributions are given in RPP-RPT-34136. 
RPP-RPT-35261, Rev. 0

\section{ANTIFOAM ADDITION TESTS}

\subsection{SUMMARY}

A series of boildown tests was performed using the Hanford boildown apparatus. The tests were designed to evaluate the effectiveness of antifoaming agents in suppressing the frothing caused by certain organic constituents ( $\mathrm{Na}_{4}$ EDTA and $\mathrm{Na}_{3} \mathrm{HEDTA}$ ) in the feed solution.

In laboratory tests at Georgia Tech (see Chapter 4), both $\mathrm{Na}_{4}$ EDTA and $\mathrm{Na}_{3}$ HEDTA were shown to cause frothing during evaporation of SST Early feed solution. In other laboratory-scale tests at other facilities (RPP-RPT-33491, Discussion of Antifoam and Foaming Issues and the 242-A Evaporator), several antifoaming agents were tested for use in vacuum evaporators. Dow Corning ${ }^{\circledR}$ Antifoam $1520-\mathrm{US}^{2}$ is currently used at the 242-A Evaporator. Dow Corning ${ }^{\circledR}$ Q2-3183A Antifoam ${ }^{3}$ has been recommended for use at the WTP.

Results of the testing in the 222-SA laboratory showed that both of the antifoaming agents tested were effective in controlling the frothing behavior within optimal antifoam concentration ranges. The optimum antifoam concentration was approximately $100 \mathrm{ppm}$ active ingredient for both antifoams.

A surprising but very important finding of the tests was that the behavior of the slurry during the boildown was heavily dependent on the age of the feed: the older the feed, the more the slurry tended to froth during boiling. This finding caused a level of complexity in interpretation of the results that had not been anticipated, which led to the necessity of performing more boildown tests than had been planned.

\subsection{TERMINOLOGY}

During the execution of the boildown tests, project personnel agreed to the following distinctions between the terms "foam" and "froth." Both a foam and a froth are volume-expanded slurries caused by entrapment of air bubbles within a liquid or solid/liquid matrix. A foam is relatively stable, i.e., the air bubbles remain entrapped for a long period of time, e.g., whipped cream. A froth is relatively unstable, i.e., the air bubbles are released relatively quickly (within minutes), and the slurry volume returns to normal. Invariably, the slurries generated during these tests would be described as froths, not foams.

In addition to frothing, slurries containing $\mathrm{Na}_{4}$ EDTA and $\mathrm{Na}_{3}$ HEDTA exhibited increased "bumping," i.e., sudden formation of large bubbles of vapor near the bottom of the slurry. In extreme cases, the bubbles, as they broke the surface, would throw slurry material onto the upper walls of the boildown pot and the walls of the apparatus above the boildown pot.

Frothing and bumping are not strictly quantifiable, but for purposes of this report, the severity levels described in Table 5-1 are used. Increased bumping was observed throughout the evaporation process in all runs that contained $\mathrm{Na}_{4}$ EDTA and $\mathrm{Na}_{3}$ HEDTA. Increased frothing appeared only after solids had formed in the boildown pot.

\footnotetext{
${ }^{2}$ Dow Coming ${ }^{\circledR}$ Antifoam 1520-US is a registered trademark of Dow Corning Corporation, Midland, Michigan.

${ }^{3}$ Dow Coming ${ }^{\circledR}$ Antifoam Q2-3183A is a registered trademark of Dow Corning Corporation, Midland, Michigan.
} 
Table 5-1. Description of Frothing and Bumping Severity Levels.

\begin{tabular}{|l|l|l|}
\hline \multicolumn{1}{|c|}{ Level } & \multicolumn{1}{c|}{ Frothing } & \multicolumn{1}{c|}{ Bumping } \\
\hline None & No increase over noncomplexed feeds & No increase over noncomplexed feeds \\
\hline Mild & $\begin{array}{l}\text { Manageable frothing occurs only immediately } \\
\text { after periodic feed additions }\end{array}$ & $\begin{array}{l}\text { Noticeable but not dramatic increase in } \\
\text { bumping }\end{array}$ \\
\hline Moderate & $\begin{array}{l}\text { Frothing is more persistent but remains below } \\
\text { boildown pot O-ring }\end{array}$ & Definite increase in bumping \\
\hline Bad & $\begin{array}{l}\text { Froth height is above O-ring but below } \\
\text { condenser }\end{array}$ & $\begin{array}{l}\text { Problematic bumping causing deposition of } \\
\text { material above O-ring }\end{array}$ \\
\hline Worse & $\begin{array}{l}\text { Frothing is unmanageable to the point that the } \\
\text { condensate is contaminated }\end{array}$ & $\begin{array}{l}\text { Unmanageable bumping causing condensate to } \\
\text { be contaminated (not observed in these tests) }\end{array}$ \\
\hline
\end{tabular}

\subsection{TEST DESCRIPTION}

Each boildown was performed using $250 \mathrm{~mL}$ of simulated SST Early feed solution spiked with $\mathrm{Na}_{4}$ EDTA and $\mathrm{Na}_{3} \mathrm{HEDTA}$, each at a concentration of $0.018 \mathrm{M}$ in the initial feed solution. The vacuum was adjusted continually to maintain an evaporation temperature of $66^{\circ} \mathrm{C}$ except for the first baseline test (Run 80, no antifoam added), which was run at $60^{\circ} \mathrm{C}$. The rate of evaporation was $\sim 40 \mathrm{~mL}$ of condensate per hour except for Run 80 , which was $25 \mathrm{~mL}$ per hour. Feed was added periodically as condensate was removed to keep the volume in the boildown pot relatively constant at $100 \mathrm{~mL}$. Throughout each test, the behavior of the slurry was observed and recorded, as well as the temperature/pressure/condensate volume at every addition of feed. At the conclusion of a test, the resulting slurry was filtered. A qualitative description of the filtering process and the final state of the crystals was recorded.

The filtration time, the total weight of the feed, the amount of slurry filtered, the amount of filtrate, and the yield of recovered crystals were measured. Also, the composition of the recovered crystals was determined by PLM. No differences were observed by PLM in any of the samples, so no further description of PLM results is necessary.

\section{$5.4 \quad$ TEST RESULTS}

The first baseline test (Run 80) was performed with $\mathrm{Na}_{4}$ EDTA and $\mathrm{Na}_{3}$ HEDTA in the feed solution but with no antifoaming agent. The behavior of the slurry was surprising in that the slurry exhibited very little of the frothing observed in similar tests at Georgia Tech (Chapter 4), and none of the water-insoluble film formation described by Georgia Tech. To more closely match the experimental conditions at Georgia Tech, the evaporation temperature was increased from 60 to $66^{\circ} \mathrm{C}$ and the evaporation rate was increased from 25 to $40 \mathrm{~mL} / \mathrm{hr}$. These changes were maintained for all subsequent tests.

Subsequent tests clearly showed that the amount of frothing observed is directly related to the age of the feed, i.e., the number of days elapsed between addition of the complexants to the feed solution and evaporation of the feed solution. Temperature and evaporation rate likely had little or no effect on the frothing characteristics. Feed aged longer than 1 week exhibited frothing similar to that described by Georgia Tech. However, the water-insoluble film described by Georgia Tech was never observed in any of these tests. The difference may be due to the type of 
apparatus used for the test - the Georgia Tech apparatus having the heating fluid circulating around the entire boiling surface, the Hanford apparatus having the heat supplied by a ceramic plate in contact with the bottom surface only. A future test is planned to repeat the Hanford test using the Georgia Tech apparatus to see if there are differences.

The reason for the increased frothing with age may be due to the breakdown of $\mathrm{Na}_{3} \mathrm{HEDTA}$ leading to formation of a decomposition product that has a much stronger effect on frothing than either $\mathrm{Na}_{4}$ EDTA or $\mathrm{Na}_{3} \mathrm{HEDTA}$. Several studies of organic aging in tank waste were completed during the 1990s (see RPP-6664, The Chemistry of Flammable Gas Generation, for a review of the literature generated on the subject). Rates of radiolytic and thermal degradation of several organic waste constituents were measured. These studies showed that $\mathrm{Na}_{3} \mathrm{HEDTA}$ decomposed much faster than $\mathrm{Na}_{4}$ EDTA in the absence of radionuclides, i.e., by the thermal degradation pathway only. However, these same studies showed that the half-life for the thermal degradation of $\mathrm{Na}_{3} \mathrm{HEDTA}$ was measured in months, not days, at elevated temperatures $\left(90^{\circ} \mathrm{C}\right)$. Therefore, it is not certain that aging of the feed for a few days at ambient laboratory temperature $\left(20^{\circ} \mathrm{C}\right)$ could have caused sufficient degradation of the $\mathrm{Na}_{3}$ HEDTA to lead to the observed increase in frothing behavior.

Table 5-2 shows a summary of the baseline tests that were performed, i.e., with no antifoaming agents added. The first data column in the table is the average of three tests performed previously with no $\mathrm{Na}_{4}$ EDTA or $\mathrm{Na}_{3} \mathrm{HEDTA}$ in the feed solution. Note that the level of frothing varies from slight intermittent frothing for 1-day-old feed (Run 80) to extreme, continuous, unmanageable frothing for 24-day-old feed (Run 92). Results for samples containing antifoaming agents must be interpreted with this time-sensitive background in mind.

Table 5-2. Summary of Baseline Test Results.

\begin{tabular}{|l|c|c|c|c|c|}
\hline \multicolumn{1}{|c|}{ Run Number } & $\mathbf{7 0 / 7 1 / 7 2 ^ { \mathbf { a } }}$ & $\mathbf{8 0}$ & $\mathbf{8 1}$ & $\mathbf{8 7}$ & $\mathbf{9 2}$ \\
\hline Temperature $\left({ }^{\circ} \mathrm{C}\right)$ & 60 & 60 & 66 & 66 & 66 \\
\hline Age of feed (days) & N/A & 1 & 3 & 14 & 24 \\
\hline Frothing & None & Mild & Moderate & Bad & Worse \\
\hline Bumping & None & Bad & Bad & Bad & Bad \\
\hline Filtration time (min) & 2.0 & 1.6 & 1.8 & 0.9 & 1.0 \\
\hline Wt $\%$ filter cake & 40.7 & 34.2 & 61.2 & 49.2 & 47.6 \\
\hline
\end{tabular}

${ }^{a}$ Average of runs $70,71,72$ from Envelope Limit boildown tests (Chapter 6).

${ }^{b}$ Weight of filter cake as percentage of the weight of slurry delivered to the filter.

Table 5-3 shows a summary of the tests with Q2-3183A antifoam. The antifoam concentrations given in the table represent the weight in grams of the undiluted antifoam per million grams of feed solution. The undiluted antifoam contains $100 \%$ "active ingredient," so the concentration of active ingredient is the same as the concentration of the undiluted antifoam.

The antifoam did not mix well with the feed solution. When added to the feed solution stirring in a glass beaker, the antifoam floated on top of the feed and would not disperse into the solution. The contents of the beaker were transferred into a plastic bottle. Vigorous shaking dispersed the antifoam, but some of the antifoam adhered to the walls of the bottle. Therefore, the true concentrations of antifoam actually dispersed in the feed solution are lower than the concentrations shown in Table 5-3. 
Table 5-3. Summary of Q2-3183A Antifoam Test Results.

\begin{tabular}{|l|c|c|c|}
\hline \multicolumn{1}{|c|}{ Run Number } & $\mathbf{8 2}$ & $\mathbf{8 3}$ & $\mathbf{8 4}$ \\
\hline Temperature $\left({ }^{\circ} \mathrm{C}\right)$ & 66 & 66 & 66 \\
\hline Age of feed (days) & 7 & 8 & 9 \\
\hline Antifoam concentration $(\mathrm{ppm})$ & 600 & 150 & 40 \\
\hline Active ingredient concentration $(\mathrm{ppm})$ & 600 & 150 & 40 \\
\hline Frothing & Mild & Mild & Moderate \\
\hline Bumping & Mild & Mild & Moderate \\
\hline Filtration time (min) & 0.95 & 0.98 & 0.90 \\
\hline Wt $\%$ filter cake & 57.5 & 50.8 & 55.7 \\
\hline
\end{tabular}

Given the age of the feed for these tests, the level of foaming would have been moderate to bad without the antifoam, and the bumping would have been bad. All three concentration levels showed dramatic improvement in both frothing and bumping, with the 40-ppm level being less effective than the higher levels. Therefore, the recommended optimum concentration for Q2-3183A antifoam would be approximately $100 \mathrm{ppm}$ (higher than $40 \mathrm{ppm}$ but no higher than $150 \mathrm{ppm})$.

Table 5-4 shows a summary of the tests with 1520-US antifoam. The undiluted antifoam contains $20 \%$ "active ingredient," so the concentration of active ingredient is five times less than the concentration of the undiluted antifoam. The same mixing problems described for the previous antifoam were observed for the 1520-US antifoam, as well.

Table 5-4. Summary of 1520-US Antifoam Test Results.

\begin{tabular}{|l|c|c|c|c|c|}
\hline \multicolumn{1}{|c|}{ Run Number } & $\mathbf{8 5}$ & $\mathbf{8 8}$ & $\mathbf{8 9}$ & $\mathbf{9 0}$ & $\mathbf{9 1}$ \\
\hline Temperature $\left({ }^{\circ} \mathrm{C}\right)$ & 66 & 66 & 66 & 66 & 66 \\
\hline Age of feed (days) & 10 & 1 & 2 & 3 & 7 \\
\hline Antifoam concentration $(\mathrm{ppm})$ & 3,000 & 6,000 & 750 & 250 & 500 \\
\hline Active ingredient concentration $(\mathrm{ppm})$ & 600 & 1200 & 150 & 50 & 100 \\
\hline Frothing & Moderate & Bad & Mild & Moderate & Mild \\
\hline Bumping & None & None & Mild & None & Mild \\
\hline Filtration time (min) & 1.5 & 2.0 & 0.80 & 0.95 & 0.95 \\
\hline $\mathrm{W} \mathrm{t} \%$ filter cake & 52.3 & 42.9 & 55.3 & 51.5 & 43.1 \\
\hline
\end{tabular}

All 1520-US antifoam levels provided adequate protection against bumping. Given the age of the feed for these tests, the level of foaming would have varied considerably without the antifoam. Interestingly, Run 88 showed worse frothing than Run 85 despite the higher antifoam concentration and the less-aged feed. The frothing in Run 85 was worse than the baseline (no antifoam) would have been after 1 day of aging. Therefore, it would appear that too much antifoam has a deleterious effect. Based on the results of Runs 89-91, an optimum active ingredient concentration for 1520-US antifoam would be approximately $100 \mathrm{ppm}$. 


\section{LOSS-OF-POWER SCENARIO TEST}

\subsection{SUMMARY}

A risk analysis was performed on the operation of the pilot plant under construction at the Savannah River Site. The worst-case accident scenario in terms of equipment damage was loss of electrical power, which would cause gradual cooling of the slurry in the evaporator body and piping, leading to loss of circulation. A boildown test with the Hanford boildown apparatus was performed to evaluate the potential consequences of this scenario.

Results of the test show that the loss-of-power scenario would likely be a recoverable event - the slurry would likely remain sufficiently pumpable to allow emptying and restarting of the evaporator.

\subsection{TEST DESCRIPTION}

The only modification to the boildown apparatus required for this test was the addition of a water bath surrounding the boildown pot to provide a heat sink that would slow down the rate of cooling of the slurry after the power was turned off. Simulated SST Early feed solution was evaporated at a constant boiling temperature of $66^{\circ} \mathrm{C}$ until the slurry reached the pilot plant evaporator steady-state operating condition of $30 \mathrm{wt} \%$ solids. Then the electrical power was turned off, stopping the heating and stirring of the slurry. The following observations were made as the slurry cooled:

$\begin{array}{ll}1: 33 \mathrm{pm} & \text { Power turned off; slurry at } 66^{\circ} \mathrm{C} . \\ 1: 43 \mathrm{pm} & \text { Boiling has stopped; slurry beginning to settle; slurry at } 67^{\circ} \mathrm{C} . \\ 1: 49 \mathrm{pm} & \text { Apparatus vented to atmospheric pressure; still } 67^{\circ} \mathrm{C} ;<1 \mathrm{~cm} \text { clear yellow } \\ & \text { liquid above settled solids; little resistance to spatula inserted into slurry. } \\ 1: 54 \mathrm{pm} & \text { Slurry at } 62^{\circ} \mathrm{C} ; 1 \mathrm{~cm} \text { clear liquid; spatula falls when inserted. } \\ 2: 04 \mathrm{pm} & 57^{\circ} \mathrm{C} \text {. } \\ 2: 16 \mathrm{pm} & 52^{\circ} \mathrm{C} ; \text { spatula falls more slowly when inserted; crust forming above } \\ & \text { liquid. } \\ 2: 33 \mathrm{pm} & 48^{\circ} \mathrm{C} ;<1 \text { cm liquid between settled solids and crust; spatula stands } \\ & \text { upright. } \\ 2: 52 \mathrm{pm} & 42^{\circ} \mathrm{C} ; \text { clear liquid becoming cloudy. } \\ 3: 14 \mathrm{pm} & 38^{\circ} \mathrm{C} ; \text { no other change. } \\ 3: 49 \mathrm{pm} & 32^{\circ} \mathrm{C} ; \text { no other change. } \\ 4: 01 \mathrm{pm} & 32^{\circ} \mathrm{C} ; \text { no other change. } \\ 8: 10 \mathrm{am} & 17^{\circ} \mathrm{C} ; \text { no change in appearance; spatula stands upright; lateral motion of } \\ & \text { spatula still possible but more difficult than previous day. } \\ 8: 20 \mathrm{am} & 17^{\circ} \mathrm{C} \text {; reassembled apparatus and turned on stirrer. } \\ 8: 40 \mathrm{am} & 17^{\circ} \mathrm{C} ; \text { turned on heat. } \\ 8: 56 \mathrm{am} & 27^{\circ} \mathrm{C} ; \text { no visible movement yet but liquid layer becoming more } \\ & \text { transparent. }\end{array}$




\begin{tabular}{|c|c|}
\hline $9: 14 \mathrm{am}$ & $37^{\circ} \mathrm{C}$; liquid layer clearer. \\
\hline $9: 38 \mathrm{am}$ & $49^{\circ} \mathrm{C}$; crust has dissolved and/or settled out. \\
\hline $9: 53 \mathrm{am}$ & $53{ }^{\circ} \mathrm{C}$; surface of settled solids beginning to undulate. \\
\hline $10: 12 \mathrm{am}$ & $\begin{array}{l}57^{\circ} \mathrm{C} \text {; clear liquid layer increased in depth to } 2 \mathrm{~cm} \text {; stirring of slurry is } \\
\text { visible; vacuum turned on. }\end{array}$ \\
\hline $10: 35 \mathrm{am}$ & $58^{\circ} \mathrm{C}$; increased evidence of stirring but slurry not yet uniform. \\
\hline $10: 41 \mathrm{am}$ & $59^{\circ} \mathrm{C}$; slurry completely mixed. \\
\hline $11: 02 \mathrm{am}$ & $65^{\circ} \mathrm{C}$; slurry beginning to boil. \\
\hline $11: 13$ am & $65^{\circ} \mathrm{C}$, steady reflux at 94 torr. \\
\hline $11: 21 \mathrm{am}$ & $65^{\circ} \mathrm{C}$; heat turned off; apparatus disassembled. \\
\hline $11: 27$ am & $\begin{array}{l}\text { Slurry from boildown pot poured into preheated steel pipe, } \\
4 \text { in. long x } 1 \text { in. inside diameter; pipe sealed at both ends and laid on its } \\
\text { side. }\end{array}$ \\
\hline $1: 30 \mathrm{pm}$ & $\begin{array}{l}\text { Plug removed from one end of pipe; slurry at } 24^{\circ} \mathrm{C} \text {; slurry does not pour } \\
\text { from pipe; spatula inserted in slurry stands upright but moves laterally } \\
\text { with ease; pipe placed in water bath to reheat. }\end{array}$ \\
\hline$: 39 \mathrm{pm}$ & Slurry at $33^{\circ} \mathrm{C}$ pours easily from pipe. Test terminated. \\
\hline
\end{tabular}

\section{PRELIMINARY ENVELOPE LIMIT TESTS}

\subsection{BACKGROUND}

The second recommendation of the independent expert review panel for fractional crystallization (RPP-28469, Technical Assessment of Fractional Crystallization for Tank Waste Pretreatment at the Department of Energy Hanford Site) stated, in part:

A suite of waste compositions must be modeled and tested before a full-scale system can be designed. A window of thermodynamically and chemically acceptable feed compositions must be established.

The "window of ... acceptable feed compositions" is referred to here as a "feed envelope." An unacceptable feed composition would be any composition that results in failure of the process to meet the separation criteria established for the program. Examples of potential failure modes include slurries with unusually high viscosity or unusually small crystals (making solid/liquid separation more difficult), excessive frothing in the evaporator, or inability to produce sufficient crystals to meet the $50 \%$ sodium recovery criterion.

Thermodynamic modeling can (and has) been used to establish envelope limits for certain waste feed components based on the ability to meet the 50\% sodium recovery criterion (RPP-34455, Hanford Medium/Low Curie Waste Pretreatment Alternatives Project-Subtask 2.1 and Subtask 2.2). However, thermodynamic modeling cannot predict kinetic effects that lead to problems like small particle size, and it cannot predict physical behaviors like excessive frothing. In addition, the thermodynamic database is known to be deficient in fluoride phosphate 
compounds known to crystallize from the waste. Therefore, some laboratory testing is required in addition to the thermodynamic modeling to establish the envelope limits.

A statistically designed envelope limit laboratory test program is currently underway and will be reported at the conclusion of the program. A preliminary set of tests was performed to evaluate some of the more critical feed components and also to develop the methodology to be used in the more extensive statistically designed test to follow. Results of the preliminary tests are reported here.

Several feed components will likely not represent a concern at any level at which they are present in dissolved saltcake. These include $\mathrm{Ca}^{2+}, \mathrm{Cl}^{-}, \mathrm{CO}_{3}{ }^{2-}, \mathrm{CrO}_{4}{ }^{2-}, \mathrm{F}^{-}, \mathrm{K}^{+}$, and $\mathrm{NO}_{3}{ }^{-}$. A list of feed components for which envelope limits need to be set is shown in Table 7-1. Hydroxide and organic component testing were deferred to the statistically designed test. Aluminate, phosphate, and sulfate levels were tested as part of the preliminary test program.

For the preliminary tests, the initial concentration of each analyte was set at the highest possible level - saturation. Although it is technically feasible that dissolved saltcake waste could achieve the highest levels of aluminate, phosphate, and sulfate tested here, such a situation is highly unlikely. Furthermore, if such an unlikely situation developed during tank waste retrieval, the problematic feed could be blended with waste from other tanks to lower the concentration of the problematic component to acceptable levels.

Table 7-1. Feed Envelope Components.

\begin{tabular}{|l|l|}
\hline \multicolumn{1}{|c|}{ Component } & \multicolumn{1}{c|}{ Concern } \\
\hline $\mathrm{OH}^{-}$ & $\begin{array}{l}\text { High hydroxide levels can lead to high liquid viscosity and tie up too much } \mathrm{Na}^{+} \text {in } \\
\text { noncrystallizable form. }\end{array}$ \\
\hline Organics & $\begin{array}{l}\text { Some organics may cause excessive frothing in the evaporator, generate water-insoluble films } \\
\text { in the slurry, generate masses of very small crystals, alter the crystal habit of product salts, and } \\
\text { generally interfere with solid/liquid separations. }\end{array}$ \\
\hline $\mathrm{Al}(\mathrm{OH})_{4}{ }^{-}$ & $\begin{array}{l}\text { High aluminate levels can lead to high liquid viscosity and tie up too much } \mathrm{Na}^{+} \text {in } \\
\text { noncrystallizable form. NaAl(OH })_{4} \text { crystals may be deleterious to solid/liquid separations. }\end{array}$ \\
\hline $\mathrm{PO}_{4}{ }^{3-}$ & $\begin{array}{l}\text { High phosphate levels can cause formation of needle-shaped crystals of } \\
\text { Na3 } \mathrm{PO}_{4} \cdot 12 \mathrm{H}_{2} \mathrm{O} \cdot 0.25 \mathrm{NaOH} \text {, which can lead to plugging of transfer pipes or the evaporator body } \\
\text { itself. }\end{array}$ \\
\hline $\mathrm{SO}_{4}{ }^{2-}$ & $\begin{array}{l}\text { Sulfate has been known to precipitate as } \mathrm{Na}_{2} \mathrm{SO}_{4}, \mathrm{Na}_{6} \mathrm{CO}_{3}\left(\mathrm{SO}_{4}\right)_{2} \text {, and } \mathrm{Na}_{3} \mathrm{FSO}_{4} \text {, all of which are } \\
\text { slow-growing, producing relatively small crystals, potentially causing difficulties in solid/liquid } \\
\text { separation. }\end{array}$ \\
\hline
\end{tabular}

\subsection{TEST DESCRIPTION}

Each boildown was performed using $250 \mathrm{~mL}$ of simulated SST Early feed solution under vacuum at a constant evaporation temperature of $60^{\circ} \mathrm{C}$. The rate of evaporation was approximately $25 \mathrm{~mL}$ of condensate per hour, which translates into a total evaporation time of approximately 6 hours. Feed was added periodically as condensate was removed to keep the volume in the boildown pot relatively constant at around $100 \mathrm{~mL}$. Throughout each test, the behavior of the slurry was observed and recorded, as well as the temperature/pressure/condensate volume at every addition of feed. At the conclusion of a test, the resulting slurry containing 
$\sim 30 \mathrm{wt} \%$ solids was filtered and the filter cake washed with a solution of sodium hydroxide, sodium nitrate, sodium carbonate, and sodium fluoride to remove the remaining interstitial liquid. A qualitative description of the filtering process and the final state of the crystals was recorded.

The filtration time, the total weight of the feed, the amount of slurry filtered, the amount of filtrate, and the yield of recovered crystals were measured. The density of the feed solutions, the condensate to feed ratio, and the percent water remaining in the filter cake after filtering were calculated. Also, the composition of the recovered crystals was determined by PLM.

Each feed solution was prepared separately by adding the necessary amounts of reagents to the stock SST Early feed solution. To prepare a saturated feed solution, $250 \mathrm{~mL}$ of SST Early was warmed to $60^{\circ} \mathrm{C}$ and the reagent (sodium aluminate, sodium phosphate, or sodium sulfate) was added in small portions until solids no longer dissolved. At that point the solution was filtered, and the filtrate was used as the reagent-saturated feed solution. To prepare a $50 \%$-saturated solution, one half of the amount of reagent needed to reach saturation was added to the SST Early feed.

\subsection{TEST RESULTS}

The key observations for each run are summarized in Table 7-2. Details of the individual runs are provided in Sections 7.3.1 through 7.3.8. Data columns in Table 7-2 are defined as follows:

a. Filtration time is a prime indicator of the ease of solid/liquid separation - faster is better.

b. Slurry behavior during the run relates to how well the slurry would behave in the plant evaporator. Severe bumping can lead to contamination of the condensate. Unusually thick (viscous) slurries make pumping and solid/liquid separation more difficult, as well as circulation within the evaporator body. "Typical" means little or no bumping or frothing.

c. Color of the washed crystals is a good indication of the effectiveness of the solid/liquid separation. The yellow color is due to the presence of chromate ion, which is present only in the liquid phase.

d. Behavior of the filtrate relates to the potential for pipe plugging in the plant downstream from the centrifuge. High-phosphate solutions are notorious for forming needle-shaped crystals that plug pipelines.

\subsubsection{Runs 70/71/72 - Baseline}

Three baseline tests using the unaltered SST Early feed were performed to refine technique, as well as to adequately describe the conditions necessary to run the process effectively with respect to the set of observations described in the test plan. The procedure went smoothly for these tests, which were characterized by a "well-behaved" slurry throughout. A "well behaved" slurry is one that produced little accumulation due to bumping or frothing and caused no problems during filtering.

There was no precipitation of crystals in the filtrate in these initial tests, and the washed filter cake was nearly white, which indicated an effective replacement of the interstitial liquid. 
Analysis of the recovered crystals by PLM showed a yield of almost exclusively sodium nitrate crystals.

Table 7-2. Summary of Preliminary Envelope Limit Test Results.

\begin{tabular}{|c|l|c|l|l|l|}
\hline $\begin{array}{c}\text { Run } \\
\text { Number }\end{array}$ & \multicolumn{1}{|c|}{ Reagent Added } & $\begin{array}{c}\text { Filtration } \\
\text { Time (min) }\end{array}$ & $\begin{array}{l}\text { Slurry Behavior } \\
\text { During Run }\end{array}$ & $\begin{array}{l}\text { Color of } \\
\text { Washed } \\
\text { Crystals }\end{array}$ & $\begin{array}{l}\text { Behavior of } \\
\text { Filtrate }\end{array}$ \\
\hline 70 & None & 2.22 & Typical & Mostly white & $\begin{array}{l}\text { No } \\
\text { precipitate }\end{array}$ \\
\hline 71 & None & 1.88 & Typical & Mostly white & $\begin{array}{l}\text { No } \\
\text { recipitate }\end{array}$ \\
\hline 72 & None & 1.80 & Typical & Mostly white & $\begin{array}{l}\text { No } \\
\text { precipitate }\end{array}$ \\
\hline 73 & Aluminate at 50\% saturation & 2.50 & Typical & $\begin{array}{l}\text { Slightly } \\
\text { yellow }\end{array}$ & $\begin{array}{l}\text { No } \\
\text { precipitate }\end{array}$ \\
\hline 74 & Saturated phosphate & 2.93 & $\begin{array}{l}\text { Thicker slurry; } \\
\text { much more } \\
\text { accumulation and } \\
\text { bumping }\end{array}$ & Light yellow & $\begin{array}{l}\text { Precipitate } \\
\text { immediately } \\
\text { on cooling }\end{array}$ \\
\hline 75 & Phosphate at 50\% saturation & 1.70 & $\begin{array}{l}\text { Some } \\
\text { accumulation and } \\
\text { bumping }\end{array}$ & Light yellow & $\begin{array}{l}\text { Precipitate } \\
\text { only after } \\
\text { cooling } \\
\text { overnight }\end{array}$ \\
\hline 76 & Phosphate at 75\% saturation & 2.00 & $\begin{array}{l}\text { Some } \\
\text { accumulation and } \\
\text { bumping }\end{array}$ & $\begin{array}{l}\text { Light yellow } \\
\text { only after } \\
\text { cooling } \\
\text { overnight }\end{array}$ \\
\hline 77 & Saturated Sulfate & $\begin{array}{l}\text { Aluminate at 50\% saturation } \\
\text { (extended run) }\end{array}$ & $\begin{array}{l}\text { Saturated aluminate } \\
\text { No } \\
\text { precipitate }\end{array}$ \\
\hline 79 & 1.88 & $\begin{array}{l}\text { Typical } \\
\text { Less bumping } \\
\text { precipitate }\end{array}$ \\
\hline
\end{tabular}

\subsubsection{Run 73 - Aluminate at 50\% Saturation (1.6 M Al)}

This test was the first with a higher concentration of aluminate in the feed solution. At first believed to be saturated in aluminate due to solids present in the feed solution, a later test (Run 79) proved this to be closer to $50 \%$ saturated at $60^{\circ} \mathrm{C}$. The solids present in the feed were determined to be aluminum hydroxide, $\mathrm{Al}(\mathrm{OH})_{3}$, which precipitated under the condition of the combination of hydroxide and aluminate concentrations present in the feed solution. The test gave similar results to the baseline tests except for a slightly longer filtering time (see Table 7-1).

\subsubsection{Run 74- Phosphate at Saturation (1.2 $\left.\mathrm{M} \mathrm{PO}_{4}{ }^{3-}\right)$}

For this test the feed solution was saturated with sodium phosphate at $60{ }^{\circ} \mathrm{C}$, and in cooling to room temperature it was necessary to add water up to a final volume of $\sim 1$ L to keep the reagent in solution. This volume was too large to run the test in a single day, so it was reduced by a preliminary evaporation of the excess water, and the test was run with $400 \mathrm{~mL}$ of feed at an increased evaporation rate. During this test, the feed solution had to be kept in a water bath at $60{ }^{\circ} \mathrm{C}$ to avoid precipitation of phosphate needles. 
This was not a well-behaved slurry. Excessive bumping of the slurry caused a large amount of accumulation, determined by PLM to be mostly phosphate crystals, and the slurry was much thicker than normal, with large needles of phosphate visually evident. A percent water analysis showed almost two-and-a-half times as much moisture was retained within the filter cake (36\% compared with $\sim 14 \%$ for the baseline runs). The percent water determination only measured total water content, so there was no distinction between interstitial water and waters of hydration present within the crystal lattice. Although the process was completed successfully, PLM analysis showed a high concentration of phosphate crystals in the final product. A feed solution containing this level of phosphate would not be an acceptable feed for the fractional crystallization process due to the high slurry viscosity and erratic behavior (bumping) of the slurry.

\subsubsection{Run 75 - Phosphate at 50\% Saturation $\left(0.60 \mathrm{MPO}_{4}{ }^{3-}\right)$}

For this test, half of the amount of sodium phosphate necessary for complete saturation was added to the feed at $60^{\circ} \mathrm{C}$. The feed was then kept at this temperature during the test to avoid increasing the volume by having to add water to keep all solids dissolved. The concentration of phosphate was low enough during this test to produce results similar to the baseline tests with the exceptions of a slightly less efficient wash, about $8 \%$ more water within the filter cake, and a product that was a mixture of sodium nitrate and sodium phosphate crystals. A feed solution containing this level of phosphate would be an acceptable feed for the process.

\subsubsection{Run 76 - Phosphate at $75 \%$ Saturation $\left(0.87 \mathrm{M} \mathrm{PO}_{4}{ }^{3-}\right)$}

Enough phosphate was added to the feed in this test to reach $75 \%$ of the saturation limit of sodium phosphate at $60^{\circ} \mathrm{C}$. The feed was kept at this temperature as during Run 75 . As expected, the results from this test appeared to lie between those of Run 74 and Run 75 . The slurry was a little thicker than the previous tests, and there was an even greater amount of accumulation when compared with Run 75. A feed solution containing this level of phosphate would not be an acceptable feed for the process.

\subsubsection{Run 76 - Sulfate at Saturation $\left(0.83 \mathrm{M} \mathrm{SO}_{4}{ }^{2-}\right)$}

For this test, the feed solution was saturated with sodium sulfate at $60^{\circ} \mathrm{C}$. The slurry was well behaved, almost exactly like the baseline tests. In comparison, there was actually less bumping than was observed during the baseline tests. The filter cake seemed to be made up of finer crystals, evident in the behavior during washing, but PLM analysis showed little, if any, difference from the baseline. There was also about 3\% less moisture present in the filter cake. A feed solution containing this level of sulfate would be an acceptable feed for the process.

\subsubsection{Run 78 - Aluminate Precipitation Kinetics (1.6 M Al)}

As the results of Run 73 were reviewed, it was considered that it might not have been an accurate representation of what would happen with an increased aluminate concentration in the feed solution. A series of tests was then created to test different theories concerning the results of Run 73. Run 78 was a replication of Run 73 but performed on an extended time scale to evaluate the effect of kinetics (i.e., slow precipitation) on the slurry. After the final addition of feed into the boildown pot, the process was left in reflux overnight to determine if interfering crystals 
might form over a long period of time. The test produced results identical to Run 73 , the only difference being a slightly faster filtering time.

\subsubsection{Run 79 - Aluminate at Saturation (2.9 M Al)}

For another test regarding the aluminate concentration in the feed solution, twice the amount believed necessary for saturation (based on Run 73) was added to the feed at $60^{\circ} \mathrm{C}$. Although the solution remained cloudy due to extremely fine precipitates, PLM analysis showed almost no crystals in solution, although sodium nitrate and needle-habit sodium aluminate crystals grew on the slide as the liquid evaporated. The fine precipitate was filtered from the solution using a 0.45-micron NALGENE ${ }^{\circledR 4}$ vacuum filter, which left a relatively clear solution. However, even smaller particles could be seen suspended within the solution, and the solution had a much higher viscosity than any of the previously prepared feed solutions. This was noted during feed additions, when the intake of solution slowed and became discontinuous in comparison with the other tests.

The boildown test performed with this feed solution produced results similar to the previous aluminate tests, except for a much thicker final slurry and a greatly increased filtering time. Filtering was extremely slow, over $5 \mathrm{~min}$ total. Thirty seconds passed with the vacuum on before any filtrate was removed from the slurry. A feed solution containing this level of aluminate would not be an acceptable feed for the process due to the extreme difficulty in separating the solids from the mother liquor.

\subsection{DISCUSSION}

At the time the preliminary envelope limit tests were designed and executed, the concentration levels of the components were based on a percentage of the saturation level. The reasoning was that feeds containing $>100 \%$ of the saturation level were impossible, so that provided a convenient upper bound for the concentration of each analyte. In the case of sulfate, feed containing sulfate at the $100 \%$ saturation level handled just as well as the baseline feed, so the saturation level is, in fact, the envelope limit for sulfate concentration. For aluminate and phosphate, the envelope limit proved to be close to $50 \%$ of the saturation level for each.

For the statistically designed envelope limit test currently in progress, concentration levels for the feed components are based on analyte:sodium mole ratios. A best-basis inventory (BBI) report was prepared (personal communication from Mike Johnson) showing the analyte:sodium mole ratios in the water-soluble fraction all of the $200 \mathrm{~W}$ Area tanks. Upper-bound limits for the statistical test were selected based on the BBI data. The mole ratios for the feed solutions in the preliminary tests were calculated after-the-fact. These ratios are shown in Table 7-3, along with the ratios for the baseline SST Early feed (which form the lower bounds for the statistical test) and for the upper bounds chosen for the statistical test.

Sections 7.4.1 and 7.4.2 describe how the preliminary envelope limit test results can be interpreted in terms of the analyte:sodium mole ratios.

\footnotetext{
${ }^{4} \mathrm{NALGENE}^{\circledR}$ is a registered trademark of Nalge Nunc International Corporation, Rochester, New York.
} 
Table 7-3. Analyte:Sodium Mole Ratios in Feed Solutions.

\begin{tabular}{|l|c|c|c|}
\hline \multicolumn{1}{|c|}{ Condition } & Aluminate:Sodium & Phosphate:Sodium & Sulfate:Sodium \\
\hline Saturated & 0.36 & 0.11 & 0.11 \\
\hline $75 \%$ saturated & -- & 0.10 & -- \\
\hline $50 \%$ saturated & 0.23 & 0.07 & -- \\
\hline SST Early (lower bound) & 0.046 & 0.007 & 0.022 \\
\hline Selected upper bound & 0.15 & 0.06 & 0.04 \\
\hline 200 W Area average & 0.060 & 0.023 & 0.018 \\
\hline
\end{tabular}

\subsubsection{Aluminate}

Keeping the aluminate concentration to less than $50 \%$ of the saturation level will avoid the problem of high liquid viscosity of the feed solution and prevent the slurry from thickening due to the formation of tiny crystals that slow the filtering process considerably. The Al:Na mole ratio at this 50\%-of-saturation level is 0.23 . As shown in Figure 7-1, this represents a concentration of aluminate that is higher than that found in most of the $200 \mathrm{~W}$ Area tanks.

Figure 7-1. Aluminum:Sodium Mole Ratios for 200 W Area Tanks.

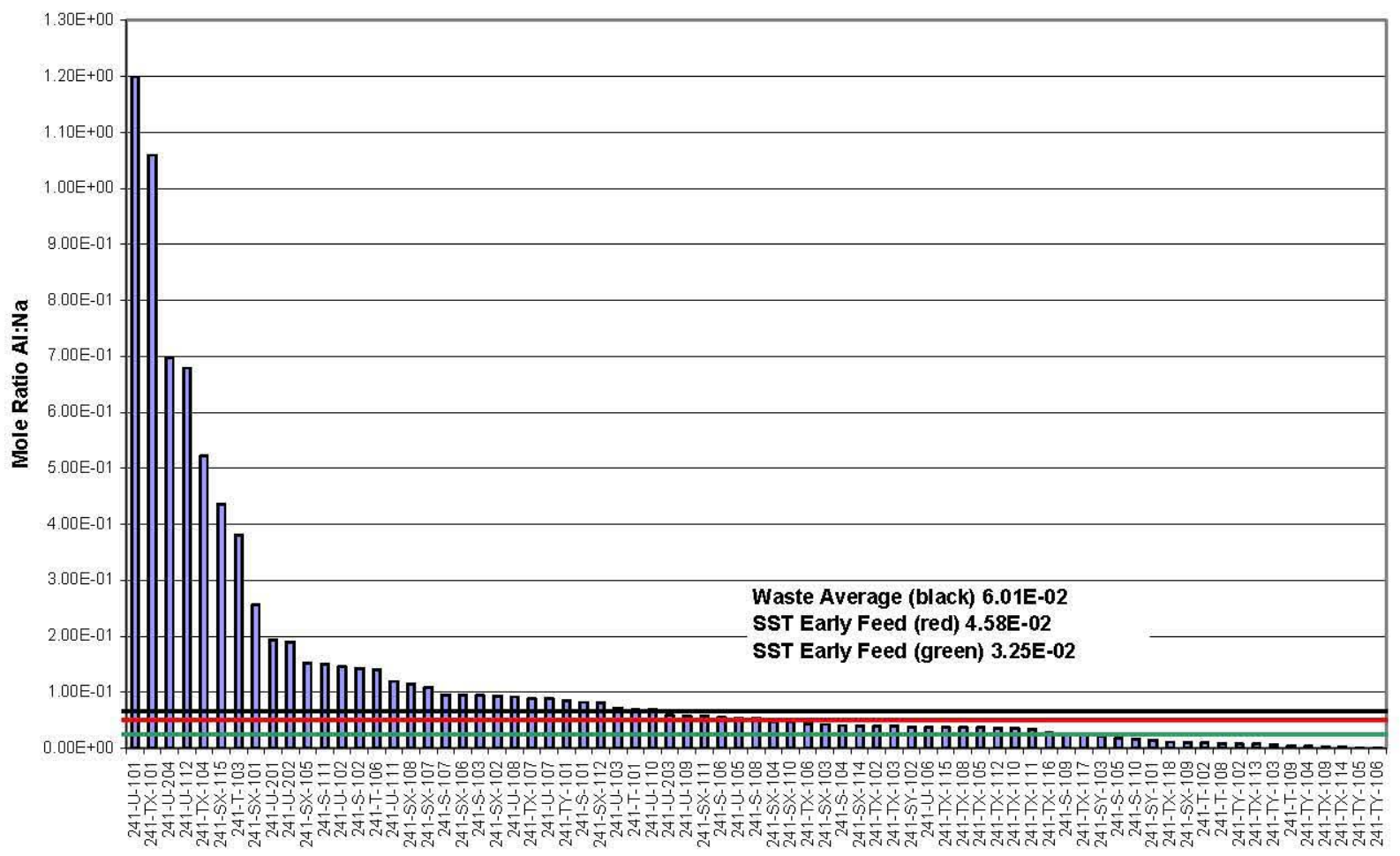

Two of the tanks shown in Figure 7-1 have completely unrealistic Al:Na mole ratios $(>1.0)$. Six more tanks have values higher than 0.23 and five of those six have values higher than 0.36 , the saturation level determined in Run 79, making them highly suspect. Only one tank falls above the 0.23 limit determined here and below the measured saturation level. For any tanks that might 
produce feed having an $\mathrm{Al}: \mathrm{Na}$ ratio higher than 0.23 , the feed could easily be blended with other low-aluminum waste to produce an acceptable feed.

\subsubsection{Phosphate}

Keeping the sodium phosphate concentration below $50 \%$ saturation is necessary to avoid the problems of a thicker slurry, excessive bumping of the slurry during evaporation, and a large amount of accumulation. The $\mathrm{PO}_{4}$ : Na mole ratio at this $50 \%$-of-saturation level is 0.07 . As shown in Figure 7-2, this is well above the 0.023 average for all of the $200 \mathrm{~W}$ Area tanks, but there are 12 tanks with higher ratios, all the way up to the theoretical limit of 0.33 for pure sodium phosphate. These 12 tanks would not be amenable to fractional crystallization processing unless blended with feed from other low-phosphate tanks.

Figure 7-2. Phosphate:Sodium Mole Ratios for 200 W Area Tanks.

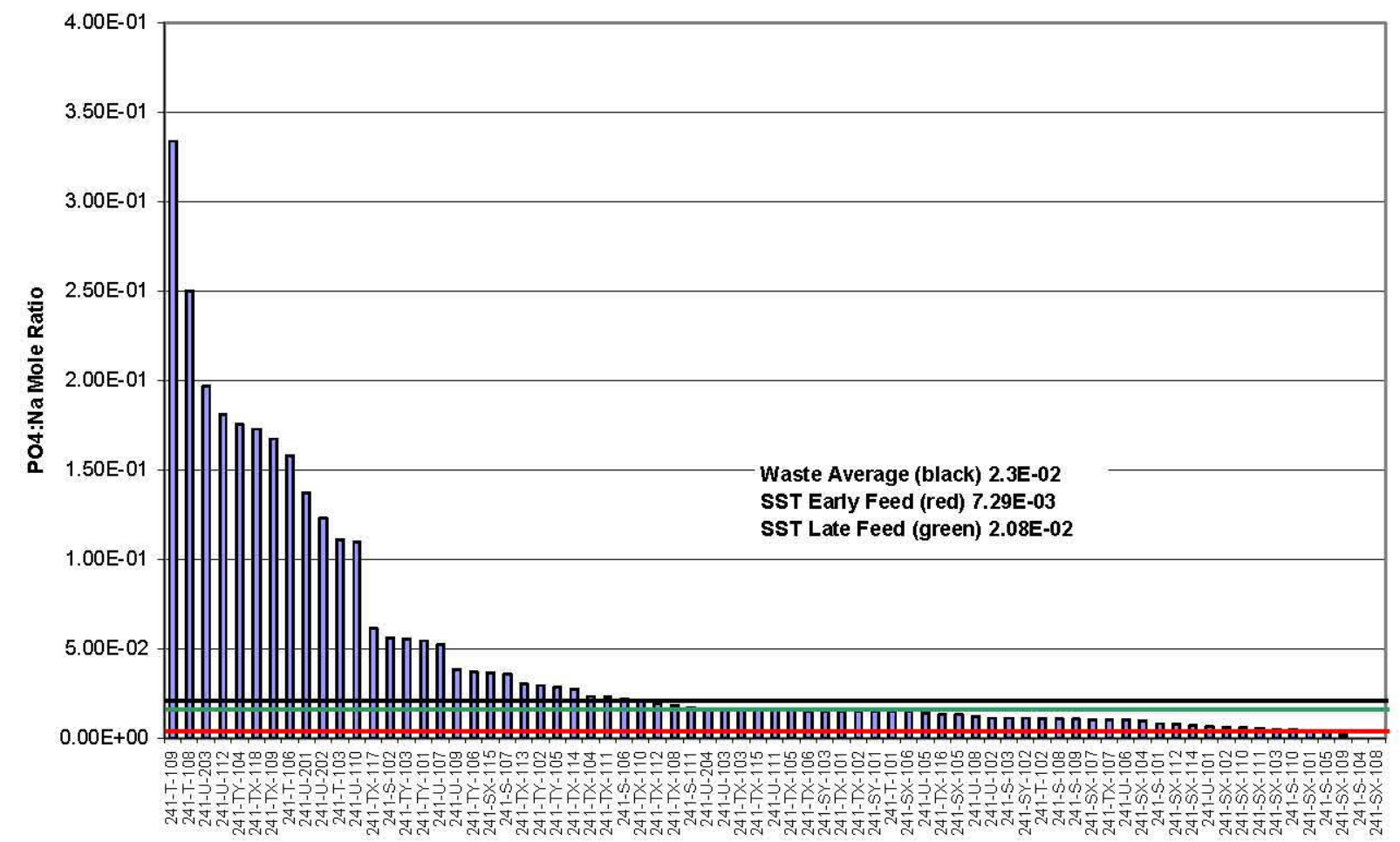

Sulfate: There is no limit to the concentration of sulfate anion in the feed that will cause problems during the process. The $\mathrm{SO}_{4}: \mathrm{Na}$ mole ratio in the saturated solution was 0.11 (see Table 7-3), which is nearly twice as high as the highest ratio seen in any $200 \mathrm{~W}$ Area tank (Figure 7-3). 
RPP-RPT-35261, Rev. 0

Figure 7-3. Sulfate:Sodium Mole Ratios for 200 W Area Tanks.

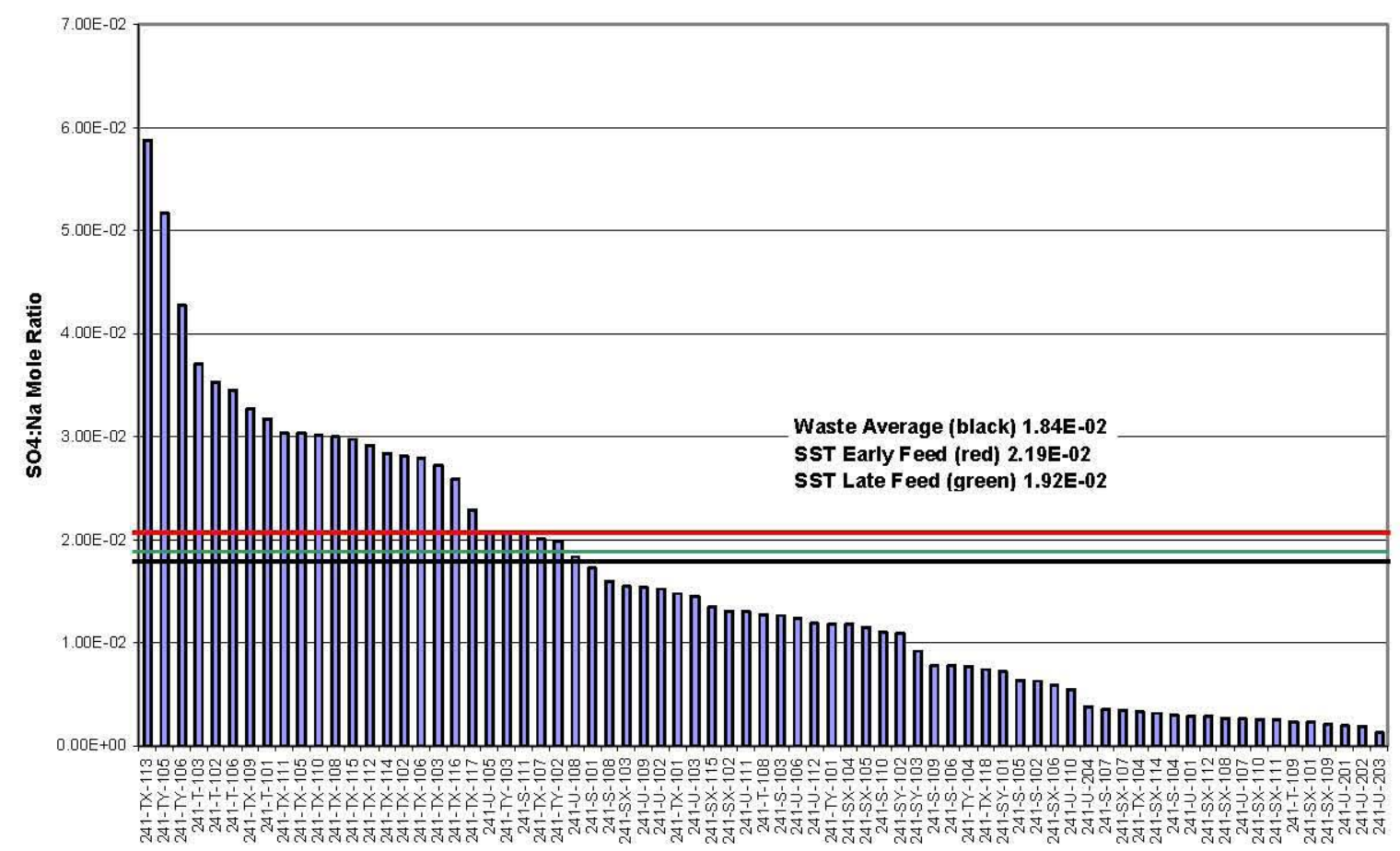

8. REFERENCES

7S110-DLH-07-101, 2007, "Report on Dissolution Rate Tests" (internal memo from D. L. Herting to D. W. Hamilton, March 8), CH2M HILL Hanford Group, Inc., Richland, Washington.

7S110-DLH-07-105, 2007, "Product Salt Recrystallization Test Results" (internal memo from D. L. Herting to D. W. Hamilton, April 9), CH2M HILL Hanford Group, Inc., Richland, Washington.

7S110-DLH-07-119, 2007, "Final Report on Dissolution Rate Tests" (internal memo from D. L. Herting to D. W. Hamilton, March 8), CH2M HILL Hanford Group, Inc., Richland, Washington.

CH2M-0602722, 2006, "Fractional Crystallization Simulant Test Comparisons" (external letter from D. L. Herting to E. A. Nelson, AREVA, December 13), CH2M HILL Hanford Group, Inc., Richland, Washington.

Ecology, EPA, and DOE, 1989, Hanford Federal Facility Agreement and Consent OrderTri-Party Agreement, 2 vols., as amended, Washington State Department of Ecology, U.S. Environmental Protection Agency, and U.S. Department of Energy, Olympia, Washington. 
RPP-34455, 2007, Hanford Medium/Low Curie Waste Pretreatment Alternatives ProjectSubtask 2.1 and Subtask 2.2, Rev. 0, CH2M HILL Hanford Group, Inc., Richland, Washington.

RPP-6664, 2001, The Chemistry of Flammable Gas Generation, Rev. 1, CH2M HILL Hanford Group, Inc., Richland, Washington.

RPP-28469, 2006, Technical Assessment of Fractional Crystallization for Tank Waste Pretreatment at the Department of Energy Hanford Site, Rev. 0, CH2M HILL Hanford Group, Inc., Richland, Washington.

RPP-PLAN-28979, 2006, Hanford Medium/Low Curie Waste Pretreatment Project-Phase II Testing and Demonstration Plan, Rev. 0, CH2M HILL Hanford Group, Inc., Richland, Washington.

RPP-RPT-26474, 2005, Fractional Crystallization of Waste from Tank 241-S-112, Rev. 0, CH2M HILL Hanford Group, Inc., Richland, Washington.

RPP-RPT-27239, 2006, Hanford Medium/Low Curie Waste Pretreatment Project-Phase I Laboratory Report, Rev. 0, CH2M HILL Hanford Group, Inc., Richland, Washington.

RPP-RPT-31352, 2007, Fractional Crystallization Flowsheet Tests with Actual Tank Waste, Rev. 1, CH2M HILL Hanford Group, Inc., Richland, Washington.

RPP-RPT-31998, 2006, Fractional Crystallization Laboratory Testing For Inclusion And Co-Precipitation with Actual Tank Waste, Rev. 0, CH2M HILL Hanford Group, Inc., Richland, Washington.

RPP-RPT-32664, 2007, Hanford Medium/Low Curie Waste Pretreatment Alternatives ProjectPhase II Testing and Demonstration Report, Subtask 2.4, Rev. 0, CH2M HILL Hanford Group, Inc., Richland, Washington.

RPP-RPT-33228, 2007, Hanford Medium/Low Curie Waste Pretreatment Alternatives ProjectPhase II Report on Pre-Pilot Work at Swenson Technology, Inc., Rev. 0, CH2M HILL Hanford Group, Inc., Richland, Washington.

RPP-RPT-33491, 2007, Discussion of Antifoam and Foaming Issues and the 242-A Evaporator, Rev. 0, CH2M HILL Hanford Group, Inc., Richland, Washington.

RPP-RPT-34136, 2007, Hanford Medium/Low Curie Waste Pretreatment Alternatives ProjectPhase II Subtask 2.5 and Subtask 2.6, Rev. 0, CH2M HILL Hanford Group, Inc., Richland, Washington. 